Pure Appl. Chem., Vol. 83, No. 4, pp. 749-768, 2011.

doi:10.1351/PAC-CON-10-11-09

(C) 2011 IUPAC, Publication date (Web): 14 March 2011

\title{
Making solar fuels by artificial photosynthesis*
}

\author{
Wenjing Song ${ }^{1}$, Zuofeng Chen ${ }^{1}$, M. Kyle Brennaman ${ }^{1}$, \\ Javier J. Concepcion ${ }^{1}$, Antonio Otávio T. Patrocinio², \\ Neyde Y. Murakami Iha ${ }^{2}$, and Thomas J. Meyer ${ }^{1, \ddagger}$ \\ ${ }^{1}$ Department of Chemistry, University of North Carolina at Chapel Hill, Chapel Hill, \\ NC 27599-3290, USA; ${ }^{2}$ Laboratory of Photochemistry and Energy Conversion, \\ Instituto de Química, Universidade de São Paulo, 05508-900, São Paulo, Brazil
}

\begin{abstract}
In order for solar energy to serve as a primary energy source, it must be paired with energy storage on a massive scale. At this scale, solar fuels and energy storage in chemical bonds is the only practical approach. Solar fuels are produced in massive amounts by photosynthesis with the reduction of $\mathrm{CO}_{2}$ by water to give carbohydrates but efficiencies are low. In photosystem II (PSII), the oxygen-producing site for photosynthesis, light absorption and sensitization trigger a cascade of coupled electron-proton transfer events with time scales ranging from picoseconds to microseconds. Oxidative equivalents are built up at the oxygen evolving complex (OEC) for water oxidation by the Kok cycle. A systematic approach to artificial photosynthesis is available based on a "modular approach" in which the separate functions of a final device are studied separately, maximized for rates and stability, and used as modules in constructing integrated devices based on molecular assemblies, nanoscale arrays, self-assembled monolayers, etc. Considerable simplification is available by adopting a "dyesensitized photoelectrosynthesis cell" (DSPEC) approach inspired by dye-sensitized solar cells (DSSCs). Water oxidation catalysis is a key feature, and significant progress has been made in developing a single-site solution and surface catalysts based on polypyridyl complexes of $\mathrm{Ru}$. In this series, ligand variations can be used to tune redox potentials and reactivity over a wide range. Water oxidation electrocatalysis has been extended to chromophorecatalyst assemblies for both water oxidation and DSPEC applications.
\end{abstract}

Keywords: artificial synthesis; $\mathrm{CO}_{2}$ reduction; proton-coupled electron transfer; solar fuel; water oxidation.

\section{INTRODUCTION: THE WORLD'S RELIANCE ON ENERGY; A SOLAR FUTURE?}

Energy is $\sim 10 \%$ of the cost of living and rising and is continuously in the news (e.g., the BP oil spill in the Gulf of Mexico, coal mine disasters in West Virginia). Inexpensive energy helped build the U.S. economy and is the key to continued growth in China, India, and East Asia, but serious questions arise about availability. Our transportation economy relies on oil but it is a finite resource. Estimates of "peak oil", when oil production peaks and begins to decline, vary widely, but most people think it will be reached sometime between 2008 and 2025 [1].

\footnotetext{
*Paper based on a presentation made at the XXIII' ${ }^{\text {rd }}$ IUPAC Symposium on Photochemistry, Ferrara, Italy, 11-16 July 2010. Other presentations are published in this issue, pp. 733-930.

¥Corresponding author: E-mail: tjmeyer@unc.edu
} 
There is also global warming to consider. Most of the world's energy needs are met by hydrocarbons (oil, coal, and natural gas). They provide $\sim 85 \%$ of energy use in the United States. When burned, hydrocarbons produce greenhouse gases $\left(\mathrm{CO}_{2}, \mathrm{SO}_{2}, \mathrm{CH}_{4}\right)$. They trap heat in the atmosphere with potentially devastating effects from sea level rise and the impact of climate change $[2,3]$.

Meeting the demands of an energy-thirsty world while avoiding environmental damage poses a major challenge for the future of the world. It is a future that will be driven by increasing energy demand and cost and environmental impact. Hydrocarbons will continue to play a major role, but costs will rise because of increasing production and process costs as the energy mix shifts away from easyto-find hydrocarbon resources. The real cost of hydrocarbons, including subsidies of various kinds, is already high with the true cost of gasoline estimated to be $>\$ 8 /$ gallon [4].

There are many energy sources to draw on-coal, oil and gas shale, nuclear, wind, biomass, geothermal—but, in the long term, the most appealing is solar. The sun is the ultimate sustainable energy source, providing 10000 times the energy that is currently consumed worldwide. Solar energy is free of greenhouse gases and pollutants and is secure, without geo-political constraints. We already use solar energy in the form of electricity from the wind, waves, and hydroelectricity, all of which are forms of concentrated solar energy. Direct solar energy is another matter. In the United States in 2008, $<1 \%$ of U.S. electric power production came from the sun.

Even given its appeal, the sun is limited as an energy source. Its energy is plentiful but diffuse; large surface areas are required for collection. To achieve the current level of power consumption in the United States of $\sim 3$ terrawatts ( $3 \mathrm{TW}$ ) at $10 \%$ efficiency would require $\sim 60000$ sq. miles for collection, roughly the area of North Carolina.

A fraction of that could come by fitting the roofs of new and existing buildings with solar collectors. Much more would be required to supply the high-density power needs of major urban areas and industrial complexes. The materials costs with current solar PV technology would be staggering, $\$ 60$ trillion for 60000 sq. miles based on today's Si solar cell technology at $\$ 400 / \mathrm{m}^{2}$.

There is an even greater drawback to solar energy. It is intermittent, disappearing with the sun at night. As an annualized global energy source, it has been estimated that there are only $6 \mathrm{~h}$ of useful sunlight per day worldwide. In order to serve as a primary energy source, solar has to be paired with an energy storage capability or capabilities on a massive scale.

Only the energy density in chemical bonds is adequate for storage at the levels required. Excess solar electrical capacity during the day could be stored as high-energy chemicals and utilized at night in existing power plants, or by secondary electricity generation in fuel cells, for example.

This leads to the concept of "solar fuels" with targets including water splitting into hydrogen and oxygen and water reduction of $\mathrm{CO}_{2}$ into almost any form of reduced carbon- $\mathrm{CO}$, formaldehyde, methanol, other oxygenates, methane-with liquid hydrocarbons as an ultimate target. Liquid fuels and natural gas are especially appealing since they would utilize our existing energy infrastructure. The chemical reactions for water splitting into hydrogen and oxygen and reduction of $\mathrm{CO}_{2}$ into methane, including the number of electrons transferred $(n)$, are shown in Scheme 1.

$$
\begin{aligned}
& 2 \mathrm{H}_{2} \mathrm{O}+4 \mathrm{hv} \rightarrow 2 \mathrm{H}_{2}+\mathrm{O}_{2} \quad\left(\Delta G^{\circ}=4.92 \mathrm{eV}, n=4\right) \\
& 2 \mathrm{H}_{2} \mathrm{O}+\mathrm{CO}_{2}+8 \mathrm{hv} \rightarrow \mathrm{CH}_{4}+2 \mathrm{O}_{2}\left(\Delta G^{\circ}=10.3 \mathrm{eV}, n=8\right)
\end{aligned}
$$

Scheme 1 Solar fuel target reactions by artificial photosynthesis.

One possible application of the solar fuels concept is shown in Fig. 1 where the $\mathrm{CO}_{2}$ produced in a natural gas power plant is captured, condensed, and transferred to a coupled solar reactor for water reduction to methane. Combining the two would create a closed cycle with no release of "greenhouse gases". 


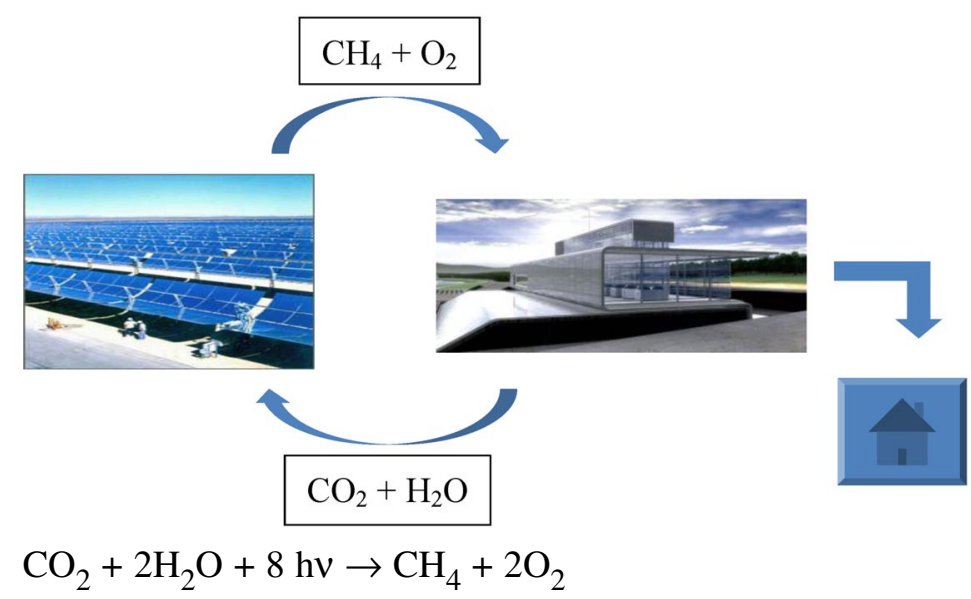

Fig. 1 A closed cycle based on burning methane to extract electrical energy and capturing $\mathrm{CO}_{2}$ for re-conversion to methane in a solar fuels reactor.

Probably the first solar fuel available in a large amount will be hydrogen because routes to water splitting are more straightforward than reduction of $\mathrm{CO}_{2}$. The promise of hydrogen as a transportation fuel may be limited because of limitations in on-board hydrogen storage, but hydrogen could be used on site in large-scale power generation. Also, when reacted with $\mathrm{CO}_{2}$, it is potentially a valuable feed stock for liquid fuels utilizing known technologies.

\section{WHAT CAN PHOTOSYNTHESIS TEACH US?}

Although the concept of solar fuels is appealing, carrying out the reactions in Scheme 1 poses a considerable challenge. Is it really possible to use sunlight to drive the reduction of $\mathrm{CO}_{2}$ by water?

In fact, "solar fuels" by $\mathrm{CO}_{2}$ reduction occurs in massive amounts by photosynthesis with $\sim 10^{10}$ tons of carbon stored annually as biomass. Although an inspiration, photosynthesis to produce biomass is too inefficient to provide a "high tech" solution for solar fuels. Overall plant solar efficiencies for biomass formation are a few percent at best. Efficiencies of $>10 \%$ are often cited as a minimum for a solar fuels device given the costs of building any imaginable solar collector.

The overall solar fuels reaction in natural photosynthesis shown in eq. 1 is solar driven reduction of $\mathrm{CO}_{2}$ by water to carbohydrates, $\left(\mathrm{CH}_{2} \mathrm{O}\right)_{n}$, rather than hydrocarbons. It is impressive in transferring $24 e^{-}$from 6 water molecules to $6 \mathrm{CO}_{2}$ molecules with the storage of $1.21 \mathrm{eV}$ in the carbohydrate product.

$$
\begin{aligned}
& 6 \mathrm{H}_{2} \mathrm{O}+6 \mathrm{CO}_{2} \rightarrow \mathrm{C}_{6} \mathrm{H}_{12} \mathrm{O}_{6}+6 \mathrm{O}_{2} \\
& \Delta G^{\circ}=29.1 \mathrm{eV}(2820 \mathrm{~kJ} / \mathrm{mol} ; 675 \mathrm{kcal} / \mathrm{mol})
\end{aligned}
$$

Photosynthesis in green plants occurs in chloroplasts which are $\sim 5 \mu \mathrm{m}$ in size with 1-1000 found in the cell walls of green plants. The photosynthetic apparatus is found within the chloroplast in the thylakoid compartment. As shown in Fig. 2, the membrane in the thylakoid compartment holds an interconnected sequence of membrane-bound functional units all of which contribute to the overall photosynthetic reaction-photosystem II (PSII), cytochrome $\mathrm{b}_{6}$ f, photosystem I (PSI), and ATP synthase. ADP is phosphorylated to ATP at ATP synthase, the key energy storage reaction in biology. $\mathrm{CO}_{2}$ is reduced in the Calvin cycle in the stroma which is outside the membrane. 


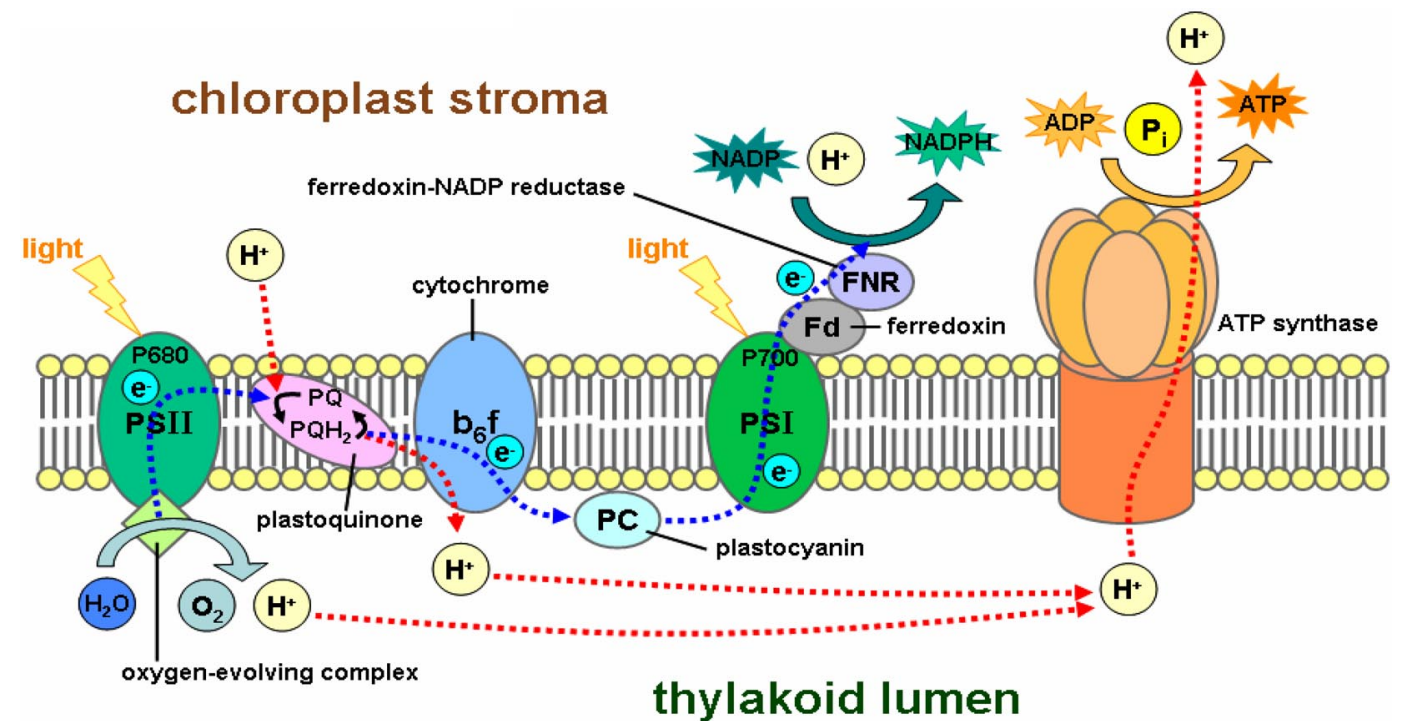

Fig. 2 Photosynthesis: Schematic arrangement of functional elements in the thylakoid membrane, from Wikipedia.

Photosynthesis is triggered by light absorption at PSII [5-13]. In the photochemistry that ensues, eq. 2, water oxidation occurs at the oxygen evolving complex (OEC) and 2 equiv of plastoquinone (PQ) are reduced to plastoquinol $\left(\mathrm{PQH}_{2}\right)$ at a site spatially separated by $\sim 50 \AA$. Once formed, $\mathrm{PQH}_{2}$ diffuses to cytochrome $\mathrm{b}_{6} \mathrm{f}$ where it undergoes electron transfer and proton release. $\mathrm{PQH}_{2}$ reduces the $\mathrm{Cu}(\mathrm{II})$ form of plastocyanin, $\mathrm{Cu}^{\mathrm{II}}(\mathrm{PC})$, to $\mathrm{Cu}(\mathrm{I})$ and it diffuses through the membrane to PSI. At PSI, it reduces the reaction center chlorophyll excited state, ${ }^{1} \mathrm{P}_{700} *+\mathrm{Cu}^{\mathrm{I}}(\mathrm{PC}) \rightarrow \mathrm{P}_{700}{ }^{-}+\mathrm{Cu}^{\mathrm{II}}(\mathrm{PC})$. This triggers a series of 7 downhill electron-transfer reactions ultimately with reduction of flavoenzyme FNR $\sim 70 \AA$ away. At FNR, a pyridinium $\left(\mathrm{NADP}^{+}\right)$is reduced to its dyhydropyridine (NADPH). NADPH provides the reductive equivalents for $\mathrm{CO}_{2}$ reduction in the Calvin cycle. The overall reaction in the combined PSII-PSI cycle is shown in eq. 3 .<smiles>CC=C(C)CCCc1cc(O)c(C)c(O)c1</smiles>

$\mathrm{PQH}_{2}$<smiles>CC(=O)C1=CN(C)C([14CH2][14CH2][14CH2][14c]2c[n+](C)ccc2C)=CC1(C)C</smiles>

$\mathrm{NADP}^{+}$
$\mathrm{NADPH}$

PSII: $2 \mathrm{H}_{2} \mathrm{O}+2 \mathrm{PQ}+4 \mathrm{hv} \rightarrow \mathrm{O}_{2}+2 \mathrm{PQH}_{2}$

$$
\text { PSII + PSI: } 2 \mathrm{H}_{2} \mathrm{O}+2 \mathrm{NADP}^{+}+4 \mathrm{hv} \rightarrow \mathrm{O}_{2}+2 \mathrm{NADPH}
$$

In addition to the stored chemical energy in $\mathrm{O}_{2}$ and $\mathrm{NADPH}$, protons released by water oxidation appear in the lumen, on the inside of the thylakoid membrane. Protons enter the membrane from the stroma, on the outside of the membrane. This produces a $\mathrm{pH}$ gradient across the membrane that is used to drive ATP production at ATP synthase.

Returning to Fig. 2 and applying a microscope to the structure of PSII reveals the structure in Fig. 3 first reported in 2004 to a resolution of $3.5 \AA$ by Barber and co-workers [14-16]. The light-driven 


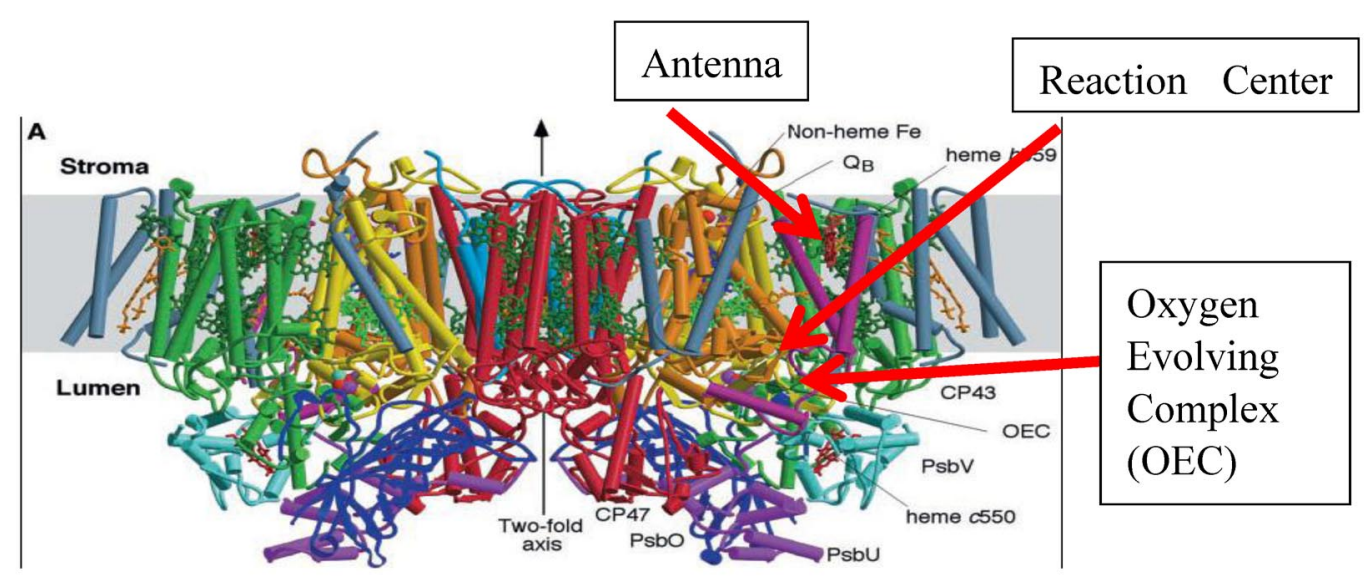

Fig. 3 Structure of PSII.

reaction at PSII is initiated by light absorption at an antenna array. The array consists of 36 chlorophyll $a$ molecules, two pheophytin $a$ molecules, and 12-16 $\beta$-carotenes per reaction center. It is remarkably efficient at light collection and sensitization of water oxidation. It delivers absorbed photons with $>90 \%$ efficiency to chlorophyll $\mathrm{P}_{680}$ giving ${ }^{1} \mathrm{P}_{680} *$ in $<1$ ps. Once the excited state forms it undergoes rapid electron transfer $(\sim 1.5 \mathrm{ps})$ to give transiently stored oxidative and reductive equivalents. The oxidative equivalents drive water oxidation to $\mathrm{O}_{2}$ at the $\mathrm{OEC}$, a $\mathrm{Mn}_{4} \mathrm{Ca}$ cluster.

The sequence of events leading to water oxidation is summarized in the modified "Kok cycle" in Fig. 4. In the Kok cycle, sequential absorption of 4 photons advances the OEC from a lowest oxidation state $\mathrm{S}_{0}\left(\mathrm{Mn}^{\mathrm{II}} \mathrm{Mn}^{\mathrm{III}} \mathrm{Mn}^{\mathrm{III}} \mathrm{Mn}^{\mathrm{IV}}\right.$ or $\left.\mathrm{Mn}^{\mathrm{III}} \mathrm{Mn}^{\mathrm{III}} \mathrm{Mn}^{\mathrm{IV}} \mathrm{Mn}^{\mathrm{IV}}\right)$ through a series of states- $\mathrm{S}_{1}, \mathrm{~S}_{2}, \mathrm{~S}_{3}, \mathrm{~S}_{4}$ - with the OEC oxidatively activated by four single-electron transfer events. The final state, $\mathrm{S}_{4}$, is a transient which rapidly releases $\mathrm{O}_{2}$. As shown in eq. 2, photoproduction of oxygen is coupled with reduction of $\mathrm{PQ}$ to $\mathrm{PQH}_{2}$.

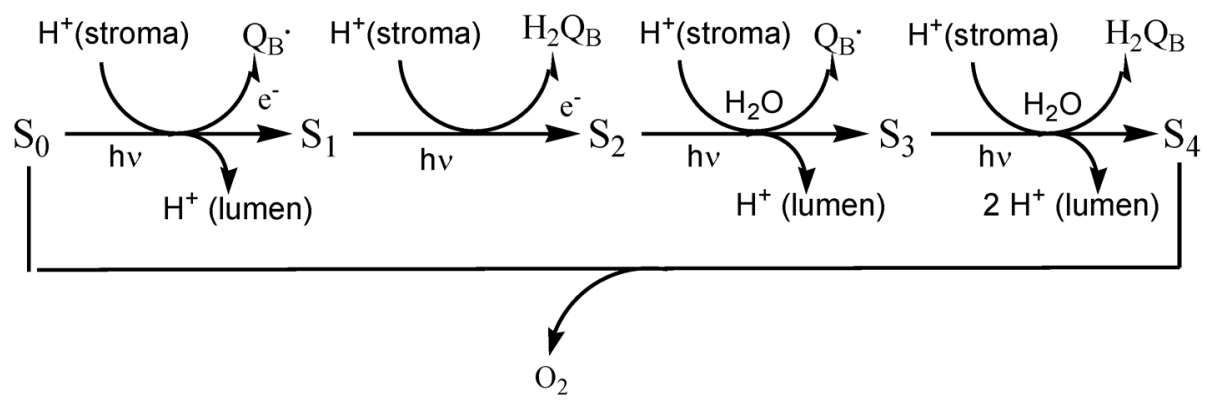

Fig. 4 Kok cycle.

As noted above, light absorption in the Kok cycle also drives proton transfer from the stroma to the lumen. Under light-saturating conditions, trans-membrane proton transfer builds up a proton gradient of $\sim 3.5 \mathrm{pH}$ units between the stroma and lumen $(\sim 0.2 \mathrm{eV})$. It is used to drive phosphorylation of ADP to ATP, ADP $+\mathrm{P}_{\mathrm{i}} \rightarrow \mathrm{ATP}\left(\mathrm{P}_{\mathrm{i}}\right.$ is inorganic phosphate) at ATP synthase.

Increasing the magnifying power of the microscope to inspect PSII even more closely reveals the structure of the reaction center in Fig. 5. Figure 5 also shows the sequence of events driven by light absorption in the initial $S_{0} \rightarrow S_{1}$ transition at the PSII reaction center. This first step, and the others in 


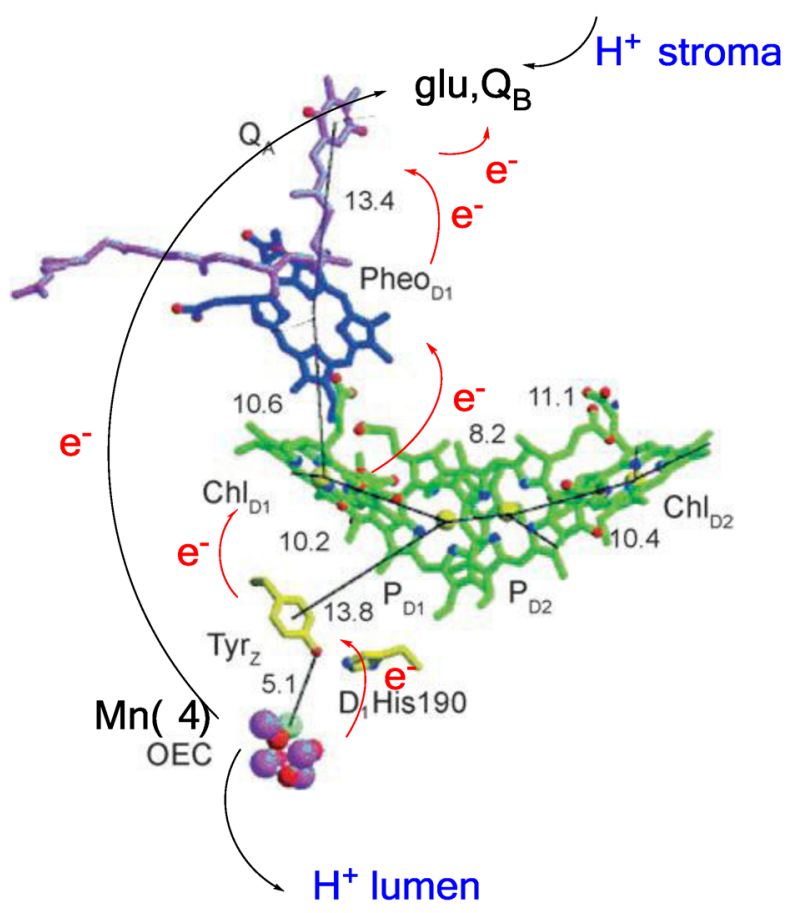

Fig. 5 Structure of the reaction center in PSII illustrating the sequence of $e^{-} / \mathrm{H}^{+}$events that occur in the $\mathrm{S}_{0} \rightarrow \mathrm{S}_{1}$ transition following single photon absorption.

the cycle, are driven by light absorption by the antenna array, sensitization of the lowest singlet excited state of chlorophyll $\mathrm{P}_{680}\left(\mathrm{Chl}_{\mathrm{D} 1}\right)$, and electron transfer quenching by pheophytin ${ }_{\mathrm{D} 1}$. As noted above, sensitization and electron transfer are efficient with $>90 \%$ excited-state sensitization occurring on the sub-ps time scale.

As illustrated in Fig. 5, excited-state electron transfer quenching triggers a cascade of five coupled electron-transfer events with time scales ranging from ps to $\mu \mathrm{s}$. All are driven by spatially directed free energy gradients achieved by placement of intermediate redox carriers in the membrane structure. Electron transfer leads to separated oxidative and reductive equivalents, the former at the OEC and the latter at quinone $\mathrm{Q}_{\mathrm{B}}$ as semiquinone, $\mathrm{Q}_{\mathrm{B}}{ }^{-}$, separated by $\sim 50 \AA$. The long separation distance is essential for slowing down back electron transfer which is in competition with catalyzed water oxidation and is relatively slow (ms).

Transmembrane proton transfer occurs indirectly. Protons released by oxidative activation of the OEC during the Kok cycle are transferred through a proton transfer channel to the lumen in $\sim 10 \mu \mathrm{s}$. Protons enter the membrane from the stroma driven by PCET reduction of PQ to $\mathrm{PQH}_{2}$.

The net reaction occurring in the $\mathrm{S}_{0} \rightarrow \mathrm{S}_{1}$ transition is shown in eq 4 .

$$
\begin{aligned}
& \left(Q_{B}, Q_{A}\right), \mathrm{Glu}^{-} \longrightarrow \mathrm{P}_{680} \ldots \mathrm{Y}_{\mathrm{Z}} \ldots \mathrm{S}_{0}\left(\mathrm{Mn}^{\mathrm{II}} \mathrm{OH}_{2}\right)+\mathrm{H}^{+}(\text {stroma })+\mathrm{hu} \longrightarrow \\
& \left(Q_{B}{ }^{-}, Q_{A}\right), \text { GlüH- }-P_{680} \ldots Y_{Z} \ldots S_{1}\left(M n n^{\text {III- }}-\mathrm{OH}\right)+H^{+} \text {(lumen) }
\end{aligned}
$$

\section{CHEMICAL APPROACHES TO ARTIFICIAL PHOTOSYNTHESIS}

The success of photosynthesis in making solar fuels is reassuring, but a question still remains as to how to achieve the same end by "artificial photosynthesis". An important lead appeared in 1972 when Honda 
and Fujushima, in a now famous experiment, demonstrated that bandgap excitation of $\mathrm{TiO}_{2}$ in the UV in a photoelectrochemical cell with a slight applied bias, resulted in water splitting into hydrogen and oxygen [17].

A basis for a second, chemical approach appeared shortly after based on molecular excitation and electron transfer. In the initial experiment, shown in Scheme 2, the goal was to demonstrate that excited states could undergo electron-transfer quenching. The reaction chosen for study was oxidative quenching of the metal-to-ligand charge transfer (MLCT) excited state of $\mathrm{Ru}(\mathrm{bpy})_{3}{ }^{2+}, \mathrm{Ru}(\mathrm{bpy})_{3}{ }^{2+*}$, by methyl

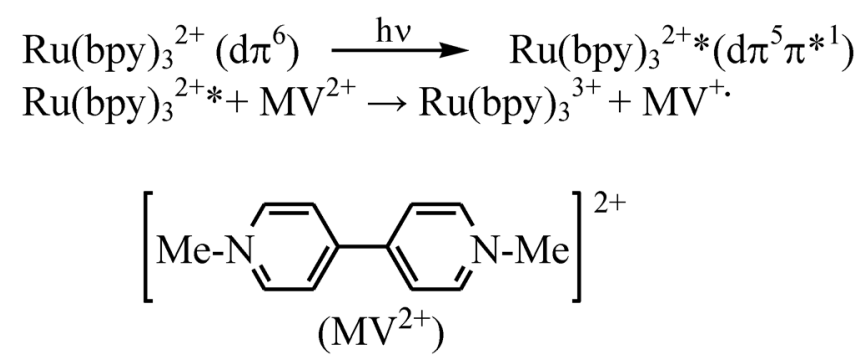

Scheme 2 Electron-transfer quenching of $\mathrm{Ru}(\mathrm{bpy})_{3}{ }^{2+*}$. Origin of a chemical approach to artificial photosynthesis.

viologen dication, $\mathrm{MV}^{2+}$. The excited state has a lifetime of $\sim 1 \mu \mathrm{s}$ and is a reasonably strong emitter. In the presence of a few $\mathrm{mM}$ of $\mathrm{MV}^{2+}$, emission is completely quenched. Flash photolysis experiments with $\mathrm{UV}$-vis monitoring demonstrated the appearance of the reduced product $\mathrm{MV}^{+\bullet}$ by appearance of its characteristic absorption spectrum. This showed that oxidative quenching had occurred to give the separated redox products $\mathrm{Ru}(\mathrm{bpy})_{3}{ }^{3+}$ and $\mathrm{MV}^{+\bullet}$, Scheme 2 [18-21].

It also opened the door to a new concept, "chemical approaches to artificial photosynthesis". Light absorption by $\mathrm{d} \pi^{6}$ ground-state $\mathrm{Ru}(\mathrm{bpy})_{3}{ }^{2+}$ to give $\mathrm{d} \pi^{5} \pi^{* 1}$ excited-state $\mathrm{Ru}(\mathrm{bpy})_{3}{ }^{2+*}$ is an energy conversion step with light energy transiently stored in the $2.1 \mathrm{eV}$ excited state. Given its $\mathrm{d} \pi^{5} \pi^{* 1}$ electronic configuration, the excited state is both a potential oxidant, by electron donation to the $\mathrm{d} \pi^{5}$ hole, and reductant, by loss of the electron in $\pi^{* 1}$. Excited-state electron transfer to $\mathrm{MV}^{2+}$ in Scheme 2 is a second energy conversion step converting excited-state energy into transiently stored oxidative and reductive redox equivalents [22-34].

Inspection of the redox potentials in Scheme 1 took the analysis one step further. The oxidized complex, $\mathrm{Ru}^{\mathrm{III}}(\mathrm{bpy}){ }_{3}{ }^{3+}$, is a powerful oxidant with $E^{\circ}(\mathrm{RuIII} / \mathrm{II})=1.26 \mathrm{~V}$ (vs. NHE) capable of oxidizing water over the entire $\mathrm{pH}$ range from 0 to 14 . The reductant, $\mathrm{MV}^{+\bullet}$, is capable of reducing $\mathrm{H}^{+}$to $\mathrm{H}_{2}$ below $\mathrm{pH} \sim 4$, which meant that water splitting into hydrogen and oxygen was energetically accessible. Although a provocative observation, much remained to be done to exploit the concept. The separated redox equivalents produced by electron-transfer quenching of $\mathrm{Ru}(\mathrm{bpy})_{3}{ }^{2+*}$ are produced in the isotropic environment of a solution without spatial control of back electron transfer, $\mathrm{Ru}^{\mathrm{III}}(\mathrm{bpy})_{3}{ }^{3+}+\mathrm{MV}^{+\bullet} \rightarrow$ $\mathrm{Ru}^{\mathrm{II}}(\mathrm{bpy})_{3}{ }^{2+}+\mathrm{MV}^{2+\bullet}$, which is favored by $1.6 \mathrm{eV}$. Back electron transfer is deleterious, releasing the transiently stored redox energy as heat to the surroundings.

The elaborate structure used in PSII is an object lesson in how to avoid back electron transfer. It utilizes structural alignment in a semi-rigid medium, free energy gradients, and sequential electron transfer to rapidly separate the initial photoproduced redox pair to $\sim 50 \AA$ to buy time for the relatively slow catalytic oxidation of water to oxygen to occur.

Analysis of the requirements for artificial photosynthesis reveals the key elements in Scheme 3, all of which can be found in PSII. Their incorporation and integration into appropriate configurations for practical devices is the major challenge in artificial photosynthesis. 
- Light absorption and/or sensitization of a molecular excited state, exciton, or nanoparticle excited state

- $\quad$ Electron-transfer quenching

- Spatially directed electron/proton transfer driven by free energy gradients to give transiently stored oxidative and reductive equivalents

- Catalysis of water oxidation and reduction of $\mathrm{H}_{2} \mathrm{O} / \mathrm{H}^{+}$or $\mathrm{CO}_{2}$

Scheme 3 Key elements for artificial photosynthesis.

A systematic basis exists for meeting the challenges posed by artificial photosynthesis based on a "modular approach" $[22,27]$. In this approach, the separate functions of a final device are studied separately, maximized for rates and stability, and used as modules in constructing integrated devices based on molecular assemblies, nanoscale arrays, self-assembled monolayers, etc.

The key modules appear in a cartoon version of an assembly for water splitting in Fig. 6. It includes an antenna array for light collection, a chromophore (C), to initiate excited-state electron transfer, chemically linked electron-transfer donors (D) and acceptors (A), and catalysts for oxidizing water $\left(\mathrm{Cat}_{\mathrm{ox}}\right)$ and reducing $\mathrm{H}^{+}$to $\mathrm{H}_{2}\left(\mathrm{Cat}_{\text {red }}\right)$. In the complete assembly, light absorption creates a chemical potential at the excited state which, through a series of $e^{-} / \mathrm{H}^{+}$transfers, drives electron transfer from $\mathrm{H}_{2} \mathrm{O}$ to $\mathrm{H}^{+}$through a free energy gradient coupled with proton transfer.

The assembly in Fig. 6 highlights the value of the "modular" approach and maximizes the performance of individual components before assembling them in a final device. It also reveals the distressingly complex nature of any assembly having the required functional elements for artificial photosynthesis. The associated synthetic challenges are formidable and unrealistic in real world applications.

Energetics, mechanism, and rate are also the key. For a molecular assembly version of the $\mathrm{Ru}^{\mathrm{III}}(\mathrm{bpy})_{3}{ }^{2+} / \mathrm{MV}^{2+}$ redox products in Scheme 2, the initial $2.1 \mathrm{eV}$ energy of the thermally equilibrated excited state is converted into $1.6 \mathrm{eV}$ of transiently stored chemical energy in the redox pair, $\mathrm{Ru}^{\mathrm{III}}(\text { bpy })_{3}{ }^{3+} / \mathrm{MV}^{+\bullet}$. This energy is available for driving the $1.23 \mathrm{~V}\left(\Delta G^{\circ}=4.92 \mathrm{eV}\right)$ water splitting reaction $\left(2 \mathrm{H}_{2} \mathrm{O} \rightarrow 2 \mathrm{H}_{2}+\mathrm{O}_{2}\right)$ or the $1.05 \mathrm{~V}$ reduction of $\mathrm{CO}_{2}$ to $\mathrm{CH}_{4}$ by $\mathrm{H}_{2} \mathrm{O}$. The catalytic steps are necessarily multi-electron transfer in character because of the high energy of the $1 e^{-}$intermediates ${ }^{\circ} \mathrm{OH}$ by $\mathrm{H}_{2} \mathrm{O}$ oxidation $\left(E^{\circ}=2.8 \mathrm{~V}\right)$ and $\mathrm{CO}_{2}^{-\bullet}$ by $\mathrm{CO}_{2}$ reduction $\left(E^{\circ}=-2.2 \mathrm{~V}\right)$.

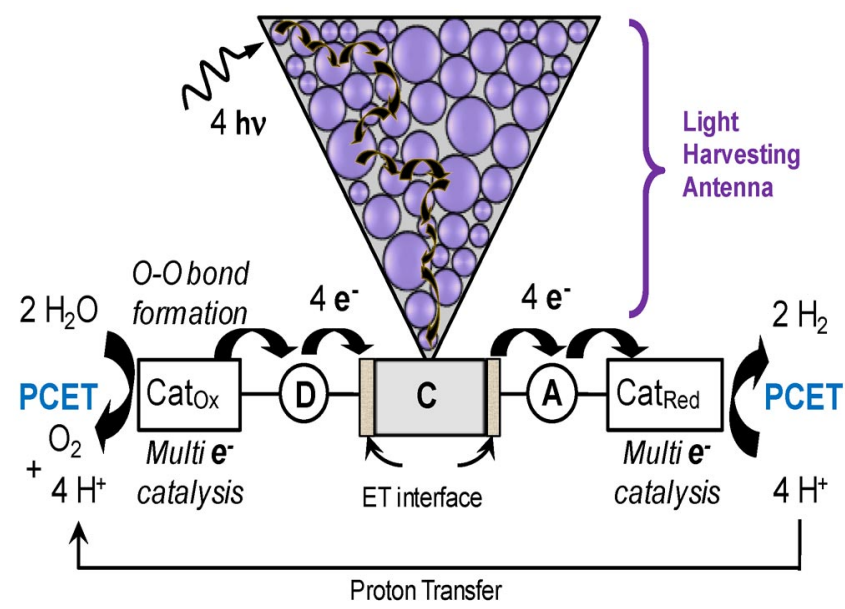

Fig. 6 Molecular assembly for artificial photosynthesis. 
Considerable simplification is available by adopting a "photoelectrosynthesis" approach with an example shown in Fig. 7. Inspired by dye-sensitized solar cells (DSSC) [35-38], this approach divides the molecular assembly into two halves in a "dye-sensitized photoelectrosynthesis cell (DSPEC)" configuration. One half is a spatially separated photoanode for water oxidation and the other a physically separated cathode for $\mathrm{CO}_{2}$ reduction. The two electrode compartments are separated by a proton exchange membrane (PEM), which allows for proton diffusion and charge balance.

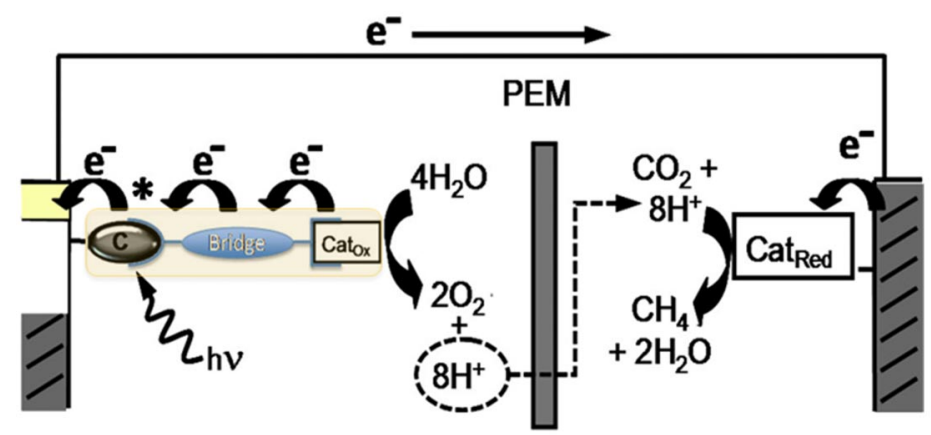

Fig. 7 DSPEC for photochemically driven reduction of $\mathrm{CO}_{2}$ to $\mathrm{CH}_{4}$. In the diagram, $\mathrm{C}$ is the light absorber (chromophore), $\mathrm{D}$ is an electron transfer donor, $\mathrm{C}_{\mathrm{ox}}$ and $\mathrm{C}_{\text {red }}$ are catalysts for water oxidation and $\mathrm{CO}_{2}$ reduction, and PEM is a proton exchange membrane such as Nafion.

The essential simplifying features, unavailable to photosynthesis, are the electrical connection between separated half reactions through an external circuit and the semiconductor acting as a photoanode. The semiconductor controls the direction of electron flow by its filled valence band, empty conduction band, and the bandgap separating them. Thin films of $\mathrm{TiO}_{2}$ are typically used on an optically transparent, conductive support either ITO $\left[\mathrm{In}_{2} \mathrm{O}_{3}\right.$ doped with $\left.\mathrm{Sn}(\mathrm{IV})\right]$ or FTO $\left(\mathrm{SnO}_{2}\right.$ doped with $\left.\mathrm{F}^{-}\right)$, The film consists of 20-40 nm sintered nanoparticles, 3-5 $\mu \mathrm{m}$ in thickness covered with an adsorbed molecular "dye" or light absorber. At these thicknesses with typical derivatized $\mathrm{Ru}(\mathrm{bpy})_{3}{ }^{2+}$ complexes as dyes, light absorption is $>90 \%$.

In the design in Fig. 7, the photoanode is a chromophore-catalyst assembly linked through the chromophore to the semiconductor by carboxylate $\left[-\mathrm{OC}(\mathrm{O})_{-}\right]$or water-stable phosphonate $[-\mathrm{O}-\mathrm{P}(\mathrm{O}) \mathrm{OH}-]$ links. The cathode is an electrode modified by surface binding of a $\mathrm{CO}_{2}$ reduction catalyst.

As in PSII, a series of events is initiated by single-photon absorption at chromophore (C) in the molecular assembly to give excited state, $\mathrm{C}^{*}$. Excitation is followed by electron injection into the conduction band of the semiconductor, $\mathrm{TiO}_{2}-\mathrm{C}^{*} \rightarrow \mathrm{TiO}_{2}\left(e^{-}\right)-\mathrm{C}^{+}$. The injected electron transfers through the mesoscopic $\mathrm{TiO}_{2}$ film to the underlying ITO or FTO electrode by small polaron hopping, where it is transferred to the cathode for $\mathrm{CO}_{2}$ reduction at $\mathrm{Cat}_{\text {red }}$. Electron transfer from the catalyst, $\mathrm{Cat}_{\mathrm{ox}}$ to $-\mathrm{C}^{+}$transfers oxidative equivalents to $\mathrm{Cat}_{\mathrm{ox}}$ where they are accumulated for the $4 e^{-}$oxidation of $\mathrm{H}_{2} \mathrm{O}$.

The bandgap characteristics of the semiconductor and its role in directing electron transfer are key. The conduction band potential of the semiconductor must be sufficiently negative to reduce $\mathrm{H}^{+}$ $\left(E^{\circ}=0 \mathrm{~V}\right)$ or $\mathrm{CO}_{2}\left[E^{\circ}\left(\mathrm{CO}_{2} / \mathrm{CH}_{4}\right)=0.38 \mathrm{~V}\right.$ with $E^{\circ} \sim 0 \mathrm{~V}$ vs. NHE for conduction band $\left.\mathrm{TiO}_{2}\left(e^{-}\right)\right]$. The photoproduced oxidative equivalent must be capable of oxidizing water to oxygen, $E^{\circ}\left(\mathrm{O}_{2} / \mathrm{H}_{2} \mathrm{O}\right)=$ $1.23 \mathrm{~V}$. Other DSPEC configurations are possible with photoelectrochemical events driven at a photocathode by hole rather than electron injection and in tandem configurations involving both photoanodes and photocathodes.

The combination of semiconductor, electrodes, and electrical connections in DSPEC devices greatly simplifies synthetic demands in ways not available to photosynthesis. It is consistent with the 
design mantra: "KEEP IT SIMPLE." This approach opens a door to working devices that could potentially be fabricated on large scales.

The feasibility of the DSPEC approach was first investigated for the dehydrogenation of isopropanol to acetone with the chromophore-catalyst assembly shown in Scheme 2. The experiment was carried out in iso-propanol as solvent with the assembly bound to $\mathrm{TiO}_{2}$ by carboxylate attachment as illustrated in the diagram accompanying the scheme [39].

The chromophore-catalyst assembly included a $-\mathrm{Ru}^{\mathrm{II}}-\mathrm{OH}_{2}{ }^{2+}$ site as a precursor for PCET oxidation to $\mathrm{Ru}^{\mathrm{IV}}=\mathrm{O}^{2+}$, see below. An extensive catalytic and mechanistic reactivity for related monomeric analogs had previously been established including oxidation of alcohols to aldehydes and ketones and, as noted below, water oxidation [40].

In Scheme 4, initial excitation and injection is followed, in a first step, by oxidation of $-\mathrm{Ru}^{\mathrm{II}}-\mathrm{OH}_{2}^{2+}$ to $-\mathrm{Ru}^{\mathrm{III}}-\mathrm{OH}^{2+}$ in the assembly. In the second step, oxidation of $-\mathrm{Ru}^{\mathrm{III}}-\mathrm{OH}^{2+}$ to $-\mathrm{Ru}^{\mathrm{IV}}=\mathrm{O}^{2+}$ occurs followed by $-\mathrm{Ru}^{\mathrm{IV}}=\mathrm{O}^{2+}$ oxidation of $i s o$-propanol to acetone. In the DSPEC, photoproduced reductive equivalents are transferred to the cathode for reduction of $\mathrm{H}^{+}$to $\mathrm{H}_{2}$ at a platinized cathode.

The net reaction was not water splitting, but it was a beginning [41-44].

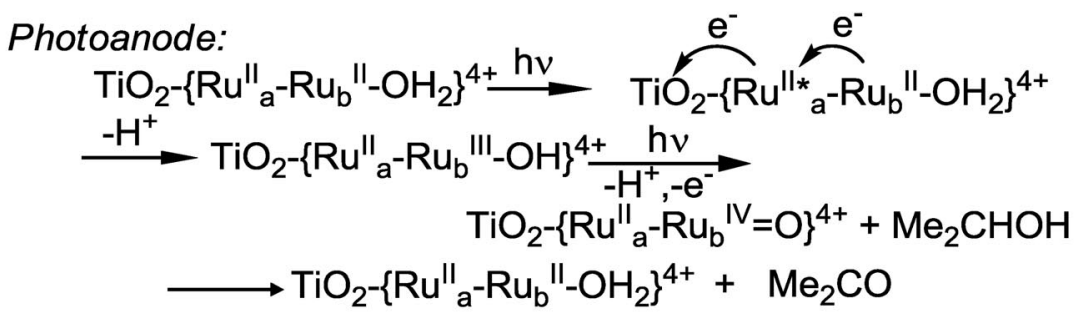

Cathode: $2 \mathrm{e}^{-}+2 \mathrm{H}^{+} \longrightarrow \mathrm{H}_{2}$

Net Reaction: $\quad\left(\mathrm{CH}_{3}\right)_{2} \mathrm{CHOH}+2 \mathrm{hv} \longrightarrow \quad\left(\mathrm{CH}_{3}\right)_{2} \mathrm{C}=\mathrm{O}+\mathrm{H}_{2}$

Scheme 4 Dehydrogenation of isopropanol by DSPEC. $\left[\mathrm{Ru}_{\mathrm{a}}-\mathrm{Ru}_{\mathrm{b}}\right]$ is $\left[\left(4,4^{\prime}-\left(\mathrm{CO}_{2} \mathrm{H}\right)_{2} \mathrm{bpy}\right)_{2} \mathrm{Ru}_{\mathrm{a}} \mathrm{II}_{(\mathrm{dpp}) \mathrm{Ru}} \mathrm{II}_{\mathrm{b}}(\mathrm{tpy})\right.$ $\left.\left(\mathrm{OH}_{2}\right)\right]^{4+}$ [dpp is 2,3-bis(2-pyridyl)pyrazine].

\section{SINGLE-SITE WATER OXIDATION}

Application of the modular approach with a DSPEC configuration simplifies the problem but significant issues remain. Chief among them is catalysis and finding ways to carry out water oxidation and $\mathrm{CO}_{2}$ or $\mathrm{H}^{+} / \mathrm{H}_{2} \mathrm{O}$ reduction with high rates and turnover numbers. The challenge comes from the multielectron, multi-proton nature of these reactions and the requirement to avoid high-energy intermediates such as ${ }^{\circ} \mathrm{OH}$ and $\mathrm{CO}_{2}{ }^{-}$. Our initial focus was on water oxidation to oxygen. At the time, the $1970 \mathrm{~s}$, there were no molecular catalysts for this reaction. We began with a modified version of $\mathrm{Ru}(\mathrm{bpy})_{3}{ }^{2+}$, cis- $\mathrm{Ru}(\mathrm{bpy})_{2}(\mathrm{py})\left(\mathrm{H}_{2} \mathrm{O}\right)^{2+}$ (py is pyridine), which combined binding of water molecule in the coordination sphere with the coordinative stability and multiple oxidation states offered by polypyridyl complexes of Ru(II) [45-47].

Chemical titrations with $\mathrm{Ce}(\mathrm{IV})$, a strong $1 e^{-}$oxidant, and electrochemical measurements uncovered something new. As shown in Scheme 5, in addition to the usual oxidation of $\mathrm{Ru}$ (II) to $\mathrm{Ru}(\mathrm{III})$, $\mathrm{Ru}(\mathrm{IV})$ was accessible and at a surprisingly low potential. Even more important was the close separation of potentials between adjacent $\mathrm{Ru}^{\mathrm{IV} / \mathrm{III}}$ and $\mathrm{Ru}^{\mathrm{III} / \mathrm{II}}$ couples with $\Delta E^{\circ \prime} \sim 0.1 \mathrm{~V}, E^{\circ \prime}$ is the formal 


$$
\begin{aligned}
& 2 \mathrm{H}_{2} \mathrm{O} \rightarrow \mathrm{O}_{2}+4 \mathrm{e}^{-}+4 \mathrm{H}^{+}
\end{aligned}
$$

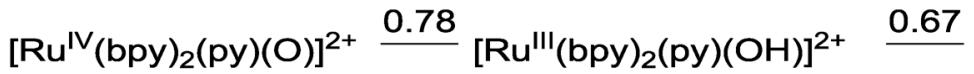

$$
\begin{aligned}
& \text { vs NHE } \\
& {\left[\mathrm{Ru}^{\prime \prime}(\mathrm{bpy})_{2}(\mathrm{py})\left(\mathrm{H}_{2} \mathrm{O}\right)\right]^{2+}} \\
& \Delta \mathrm{E}^{01}=0.11 \mathrm{~V} \\
& 2 \mathrm{Ru}^{\mathrm{IV}}(\text { bpy })_{2}(\text { py })(\mathrm{O})^{2+}+2 \mathrm{H}_{2} \mathrm{O} \rightarrow 2 \mathrm{Ru}^{\mathrm{II}}(\text { bpy })_{2}(\text { py })\left(\mathrm{H}_{2} \mathrm{O}\right)^{2+}+\mathrm{O}_{2} \\
& \left(\mathrm{E}^{\mathrm{o}}(\mathrm{pH} 7)=-0.10 \mathrm{~V}\right)
\end{aligned}
$$

Scheme 5 Redox potential leveling by PCET, at $\mathrm{pH}=7$ vs. NHE.

potential. This compares with typical $\Delta E^{\circ 1}$ values of $0.5-1.5 \mathrm{~V}$ for $\mathrm{pH}$ independent organic and inorganic couples.

Small $\Delta E^{\circ}$ values between adjacent couples is essential for building up the oxidative equivalents for water oxidation in eq 5 . It is small for the $\mathrm{Ru}^{\mathrm{IV} / \mathrm{III}}-\mathrm{Ru}^{\mathrm{III} / \mathrm{II}}$ couples because of their $1 e^{-} / 1 \mathrm{H}^{+}$, protoncoupled electron transfer $\left(\right.$ PCET) character $-\mathrm{Ru}^{\mathrm{IV}}=\mathrm{O}^{2+} / \mathrm{Ru}^{\mathrm{III}}-\mathrm{OH}^{2+} ; \mathrm{Ru}^{\mathrm{III}}-\mathrm{OH}^{2+} / \mathrm{Ru}^{\mathrm{II}}-\mathrm{OH}_{2}{ }^{2+\bullet}$ PCET avoids charge build up and leads to "redox potential leveling", Scheme 5 [46,48-49].

Oxidation from $\mathrm{Ru}^{\mathrm{II}}-\mathrm{OH}_{2}{ }^{2+}$ to $\mathrm{Ru}^{\mathrm{IV}}=\mathrm{O}^{2+}$ also met half of the $e^{-} / \mathrm{H}^{+}$loss requirement for water oxidation but $c i s-\mathrm{Ru}(\mathrm{bpy})_{2}(\mathrm{py})\left(\mathrm{H}_{2} \mathrm{O}\right)^{2+}$ was not a catalyst for water oxidation. The $E^{\text {or }}$ value for the $\mathrm{Ru}^{\mathrm{IV}}=\mathrm{O}^{2+} / \mathrm{Ru}^{\mathrm{II}}-\mathrm{OH}_{2}{ }^{2+}$ couple fell $0.1 \mathrm{~V}$ short of being able to carry out the reaction.

In a second attempt, we investigated a $\mu$-oxo bridged analog of cis- $\mathrm{Ru}(\mathrm{bpy})_{2}(\mathrm{py})\left(\mathrm{H}_{2} \mathrm{O}\right)^{2+}$, the "blue Ru dimer", cis, cis-(bpy $)_{2}\left(\mathrm{H}_{2} \mathrm{O}\right) \mathrm{RuORu}\left(\mathrm{OH}_{2}\right)(\text { bpy })_{2}{ }^{4+}$, Fig. 8 [50-54].

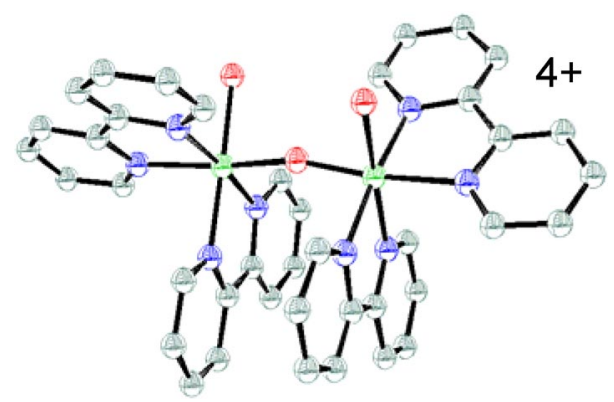

Fig. 8 Structure of the water oxidation catalyst cis, cis-(bpy $)_{2}\left(\mathrm{H}_{2} \mathrm{O}\right) \mathrm{RuORu}\left(\mathrm{OH}_{2}\right)(\mathrm{bpy})_{2}{ }^{4+}$.

The strategy here was obvious- provide two $\mathrm{Ru}-\mathrm{OH}_{2}$ sites with a chemical bridge for possible $4 e^{-} / 4 \mathrm{H}^{+}$oxidation in a single molecule. However, there were significant differences between cis-Ru(bpy $)_{2}(\mathrm{py})\left(\mathrm{H}_{2} \mathrm{O}\right)^{2+}$ and the blue dimer due to the effect of strong electronic coupling across the $\mu$-oxo bridge. Extensive orbital mixing with the $\mu$-oxo bridge increases electron content at the metal ions significantly shifting $E^{\circ}$ values considerably to negative potentials.

Kinetic studies with $\mathrm{Ce}(\mathrm{IV})$ as oxidant revealed an oxidative activation mechanism involving a series of four sequential $1 e^{-}$transfer steps. With loss of $3 e^{-},(\mathrm{bpy})_{2}(\mathrm{O}) \mathrm{Ru}^{\mathrm{V}} \mathrm{ORu}{ }^{\mathrm{IV}}(\mathrm{O})(\mathrm{bpy})_{2}{ }^{3+}$ appeared 
as an observable intermediate. It was oxidized further to (bpy $)_{2}(\mathrm{O}) \mathrm{Ru}^{\mathrm{V}} \mathrm{ORu} \mathrm{V}_{(\mathrm{O})}(\mathrm{bpy})_{2}{ }^{4+}$ but the latter only as a transient. Once formed, it underwent a rapid reaction with $\mathrm{H}_{2} \mathrm{O}$ to give a peroxidic intermediate, $(\mathrm{HOO}) \mathrm{Ru}^{\mathrm{IV}} \mathrm{ORu}^{\mathrm{IV}}(\mathrm{OH})^{4+}$. Further oxidation resulted in oxygen release, eq 7 .

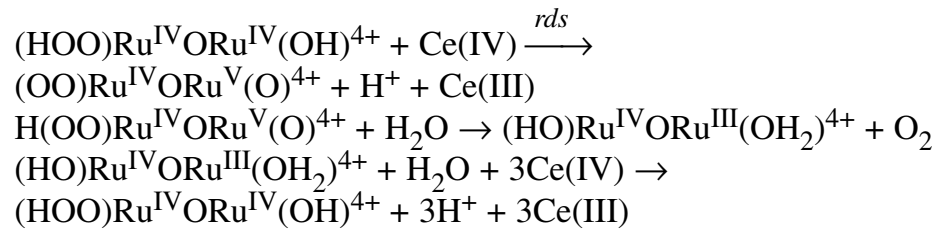

There were complications with the blue dimer from anion coordination induced by water oxidation which slowed down catalytic cycles inhibiting catalysis [50]. With this limitation recognized, we returned to the single-site approach, utilizing the well-developed synthetic chemistry of polypyridyl complexes of Ru. As noted above, this class of complexes has the great advantage of being stable in multiple oxidation states with the added bonus of a well-developed synthetic chemistry allowing ligand variations to be used to tune redox potentials and reactivity over a wide range.

Addition of excess $\mathrm{Ce}(\mathrm{IV})$ to acidic aqueous solutions containing $\mathrm{Ru}(\mathrm{tpy})(\mathrm{bpm}) \mathrm{OH}_{2}{ }^{2+}$ (tpy is $2,2^{\prime}, 2^{\prime \prime}$-terpyridine; bpm is $2,2^{\prime}$-bipyrimidine) or $\mathrm{Ru}(\mathrm{tpy})(\mathrm{bpz}) \mathrm{OH}_{2}{ }^{2+}$ (bpz is 2,2'-bipyrazine) led to catalytic water oxidation [55,56]. A kinetic and mechanistic investigation established the cycle of coupled reactions in Scheme 6 with the appearance of $\mathrm{Ru}^{\mathrm{V}}=\mathrm{O}^{3+}$ as a key intermediate. It is formed by sequential PCET oxidative activation of $\mathrm{Ru}^{\mathrm{II}}-\mathrm{OH}_{2}{ }^{2+}$ to $\mathrm{Ru}^{\mathrm{IV}}=\mathrm{O}^{2+}$ followed by $1 e^{-}$oxidation of $\mathrm{Ru}^{\mathrm{IV}}=\mathrm{O}^{2+}$ to $\mathrm{Ru}^{\mathrm{V}}=\mathrm{O}^{3+}$. In the key $\mathrm{O} \cdots \mathrm{O}$ bond-forming step, $\mathrm{Ru}^{\mathrm{V}}=\mathrm{O}^{3+}$ undergoes $\mathrm{O}$-atom attack on water to give the peroxidic intermediate, $\mathrm{Ru}^{\mathrm{III}}-\mathrm{OOH}^{2+}$. Further oxidation of the peroxide occurs to $\mathrm{Ru}^{\mathrm{IV}}(\mathrm{OO})^{2+}$ followed by slow $\mathrm{O}_{2}$ release or further oxidation by $\mathrm{Ce}(\mathrm{IV})$ to $\mathrm{Ru}^{\mathrm{V}}(\mathrm{OO})^{3+}$ which rapidly releases $\mathrm{O}_{2}$. Either, or a combination of the two, completes a cycle for Ce(IV)-driven water oxidation [55,57].

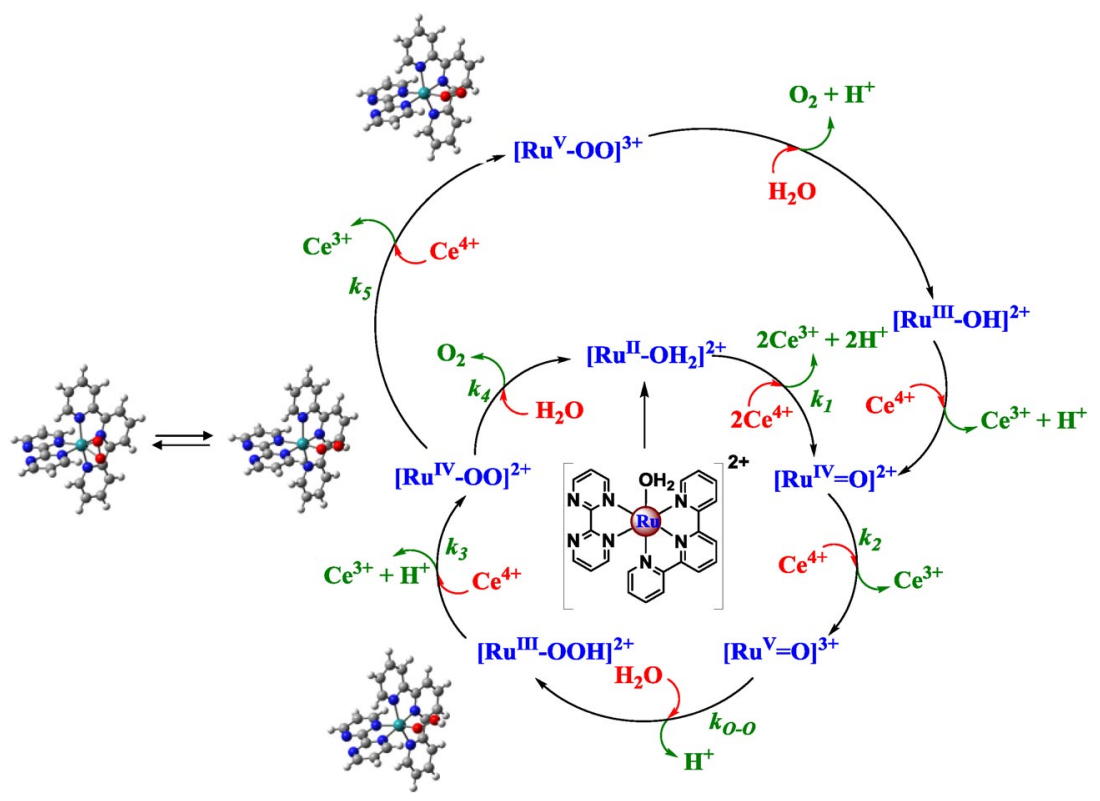

Scheme 6 Mechanism of catalytic water oxidation by $\mathrm{Ru}($ tpy $)(\mathrm{bpm}) \mathrm{OH}_{2}{ }^{2+}$ and $\mathrm{Ru}(\mathrm{tpy})(\mathrm{bpz}) \mathrm{OH}_{2}{ }^{2+}$ with $\mathrm{Ce}(\mathrm{IV})$ as the oxidant in $0.1 \mathrm{M} \mathrm{HNO}_{3}: 4 \mathrm{Ce}(\mathrm{IV})+2 \mathrm{H}_{2} \mathrm{O} \rightarrow 4 \mathrm{Ce}(\mathrm{IIII})+\mathrm{O}_{2}+4 \mathrm{H}^{+}$. 
The key peroxidic intermediates have, so far, been identified by spectroscopic measurements (UV-vis, EPR, Raman) and redox titrations. Application of density functional theory (DFT) has given the energy-minimized structures shown in Scheme 6. There is considerable literature precedent for the $\mathrm{Ru}^{\mathrm{IV}}(\mathrm{OO})^{2+}$ structure with the lowest energy form a chelating, 7-coordinate peroxide. The most appropriate description of the further oxidized form, $\mathrm{Ru}^{\mathrm{V}}(\mathrm{OO})^{3+}$, is an $\mathrm{O}_{2}$ complex of $\mathrm{Ru}(\mathrm{III})$, consistent with rapid $\mathrm{O}_{2}$ release.

With excess $\mathrm{Ce}(\mathrm{IV})$, the rate-limiting step in Scheme 6 is $\mathrm{O}-\mathrm{O}$ coupling with $k_{\mathrm{O}-\mathrm{O}}=9.6 \times$ $10^{-3} \mathrm{~s}^{-1}\left(t_{1 / 2} \sim 70 \mathrm{~s}\right)$. Although an encouraging start, the measured rate was far slower than needed to make sure that the rate-limiting step in a working device is the rate of solar insolation. In PSII, with ambient sunlight, the turnover rate at the reaction center is $\sim 1 \mathrm{~ms}$ which matches the solar insolation rate. In a DSPEC device this translates into a rate of $\sim 10 \mathrm{~mA} / \mathrm{cm}^{2}$ as a lower limit. Faster rates are desirable in order to take advantage of solar collector technology to collect and focus the light on an active solar fuel panel.

Single-site water oxidation catalysis has progressed rapidly [58-60]. Multiple Ru-based catalysts have been identified and characterized based on a variety of ligand sets. Examples are illustrated in Fig. 9. They make it possible to tune redox potentials to control rates and onset potentials for water oxidation. They have also been used to "downtune" reactivity toward water oxidation for exploitation in organic oxidations.

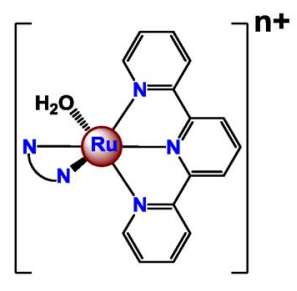

tpy series

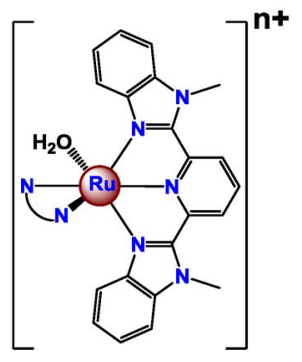

Mebimpy series

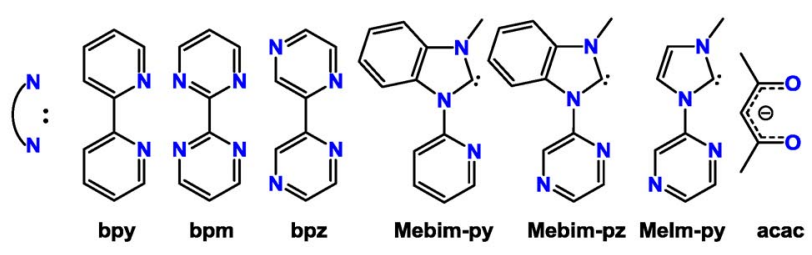

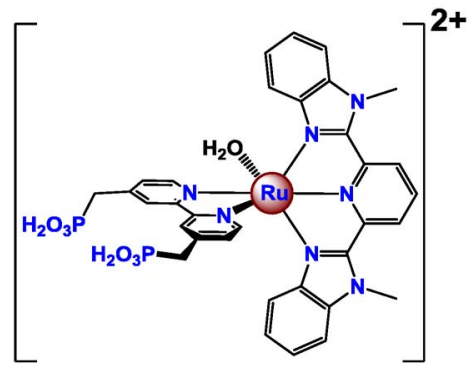

$\left[\mathrm{Ru}\left(\text { Mebimpy) }\left(\left(4^{\prime} 4^{\prime}-\mathrm{H}_{2} \mathrm{O}_{3} \mathrm{PCH}_{2}\right)_{2}-\mathrm{bpy}\right)\left(\mathrm{OH}_{2}\right)\right]^{2+}\right.$

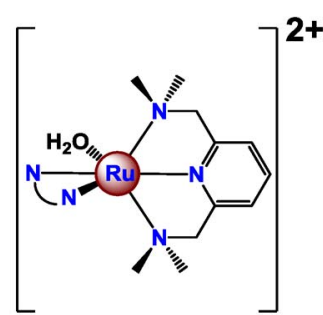

$\left[\mathrm{Ru}(\mathrm{DMAP})(\mathrm{NN})\left(\mathrm{OH}_{2}\right)\right]^{2+}$

Fig. 9 Structures of water oxidation catalysts. 
Notable in the list of water oxidation catalysts is the phosphonate $\left[-\mathrm{P}(\mathrm{O})(\mathrm{OH})_{2}\right]$ derivatized complex $\mathrm{Ru}$ (Mebimpy) $\left[4,4^{\prime}-\left(\mathrm{H}_{2} \mathrm{O}_{3} \mathrm{PCH}_{2}\right)_{2}\right.$ bpy $]\left(\mathrm{H}_{2} \mathrm{O}\right)^{2+}$. In contrast to the carboxylate binding strategy used for the chromophore-catalyst assembly in Scheme 4, phosphonates give water-stable surface binding in acidic solutions by using multiple $\mathrm{M}-\mathrm{O}-\mathrm{P}$ interactions with the surface. Phosphonate binding provides a general way to position water oxidation catalysts on a variety of oxide surfaces in interfacial configurations appropriate for device applications including the DSPEC configuration in Fig. 7 [56,61].

Water oxidation catalysis by surface binding of the phosphonate-derivatized complex in Fig. 9 on nanoITO has been studied in detail $[59,61]$. NanoITO, a new material, developed in the UNC Energy Frontier Research Center (EFRC), is both optically transparent and conductive. Top-down and crosssection scanning electron microscopy (SEM) images are shown in Fig. 10. The combined optical transparency and conductivity of nanoITO allows key intermediates to be generated and monitored by $\mathrm{UV}$-vis measurements [62].

\section{top-down}

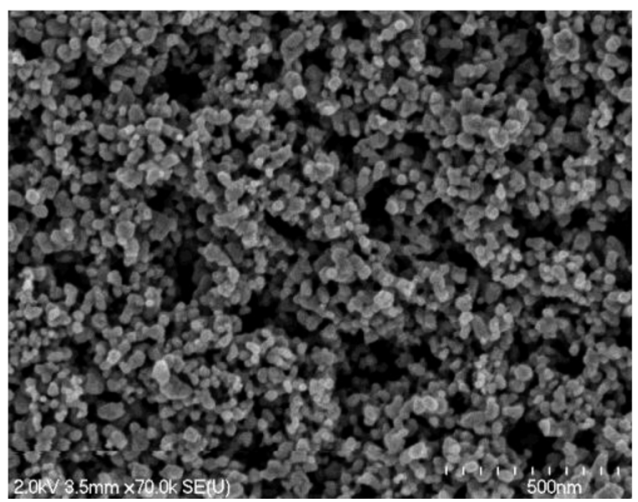

\section{cross-section}

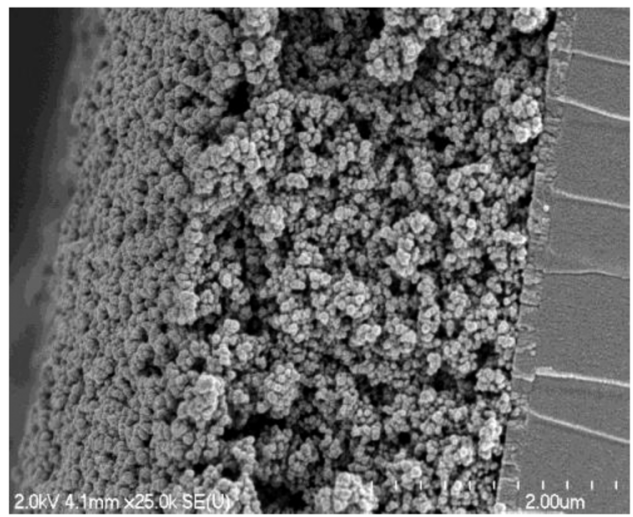

Fig. 10 SEM images of a ITO Film on FTO prepared by a sol-gel procedure producing uniform 40-nm particles.

A striking example is shown in Fig. 11. It documents UV-vis spectral changes during oxidative-reductive scans of the catalyst $\left\{\mathrm{Ru}(\text { Mebimpy })\left(4,4^{\prime}-\left[(\mathrm{HO})_{2} \mathrm{P}(\mathrm{O}) \mathrm{CH}_{2}\right)_{2} \text { bpy }\right]\left(\mathrm{H}_{2} \mathrm{O}\right)\right\}^{2+}$ on nanoITO $\left(\mathbf{1}-\mathrm{PO}_{3} \mathbf{H}_{2}\right)$. Notable is the appearance of signature spectra for the peroxidic intermediates in Scheme 6- $\mathrm{Ru}^{\mathrm{IV}}(\mathrm{OO})^{2+}, \mathrm{Ru}^{\mathrm{III}} \mathrm{OOH}^{2+}$, and $\mathrm{Ru}^{\mathrm{II}}(\mathrm{HOOH})^{2+}$. The spectral changes observed in Fig. 11 are consistent with the sequence of reactions in $\mathrm{a}-\mathrm{h}$.

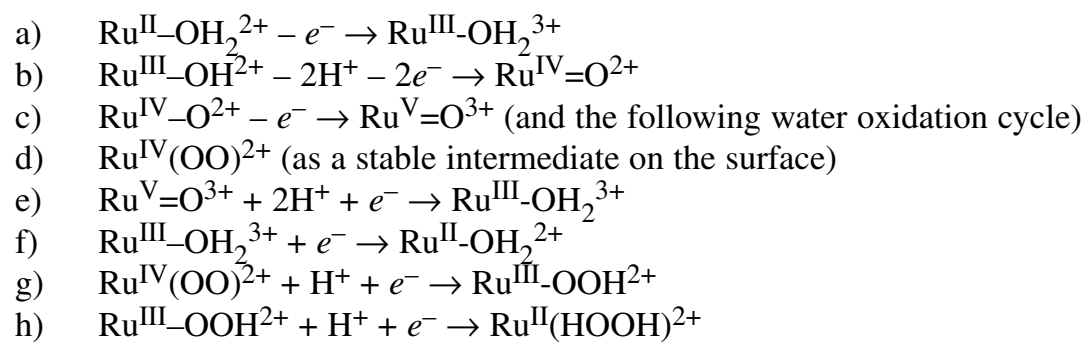




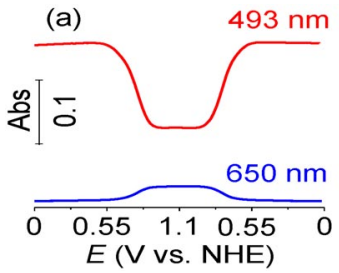

(c)

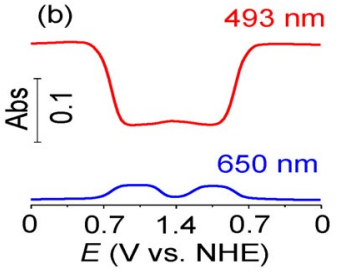

$493 \mathrm{~nm}$

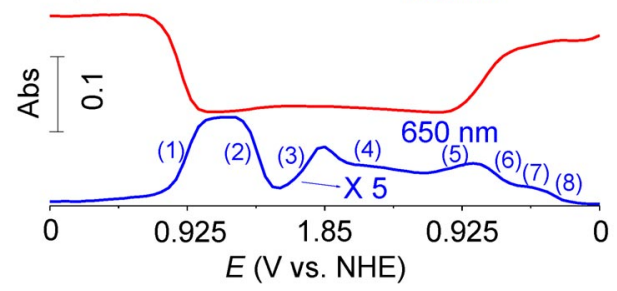

Fig. 11 Spectral evolution of ITO|nanoITO|1- $\mathrm{PO}_{3} \mathrm{H}_{2}$ at $\mathrm{pH} 1\left(0.1 \mathrm{M} \mathrm{HNO}_{3}\right)$ during $\mathrm{CV}$ scans between: (a) 0-1.1 $\mathrm{V}$, (b) $0-1.4 \mathrm{~V}$, and (c) $0-1.85 \mathrm{~V}$. The monitoring wave lengths are $\lambda_{\max }=493 \mathrm{~nm}$ for $\mathrm{Ru}^{\mathrm{II}}-\mathrm{OH}_{2}{ }^{2+}$ and $\mathrm{Ru}^{\mathrm{II}}(\mathrm{HOOH})^{2+}$ (top curve), and $\lambda_{\max }=650 \mathrm{~nm}$ for $\mathrm{Ru}^{\mathrm{III}}-\mathrm{OH}_{2}{ }^{3+}$ and $\mathrm{Ru}^{\mathrm{max}}-\mathrm{OOH}^{2+}$ (bottom curve): scan rate, $10 \mathrm{mV} / \mathrm{s}$. For clarity, the bottom curve in (c) was magnified by 5 -fold. The sequence of electrochemical/chemical events is keyed to the sequence of reactions in $\mathrm{a}-\mathrm{h}$.

Figure 12 shows the electrode response and sustained current that ensues following surface oxidation of $\mathrm{Ru}($ Mebimpy $)\left[4,4 "-\left(\mathrm{H}_{2} \mathrm{O}_{3} \mathrm{PCH}_{2}\right)_{2}\right.$ bpy $]\left(\mathrm{H}_{2} \mathrm{O}\right)^{2+}$ on $\mathrm{FTO}$ at $+1.85 \mathrm{~V}$, past $E_{\mathrm{p}}$ for oxidation of the intermediate $\mathrm{Ru}^{\mathrm{IV}}(\mathrm{OO})^{2+}$. Water oxidation catalysis on the surface was sustained with no sign of diminution after 11000 turnovers [59].
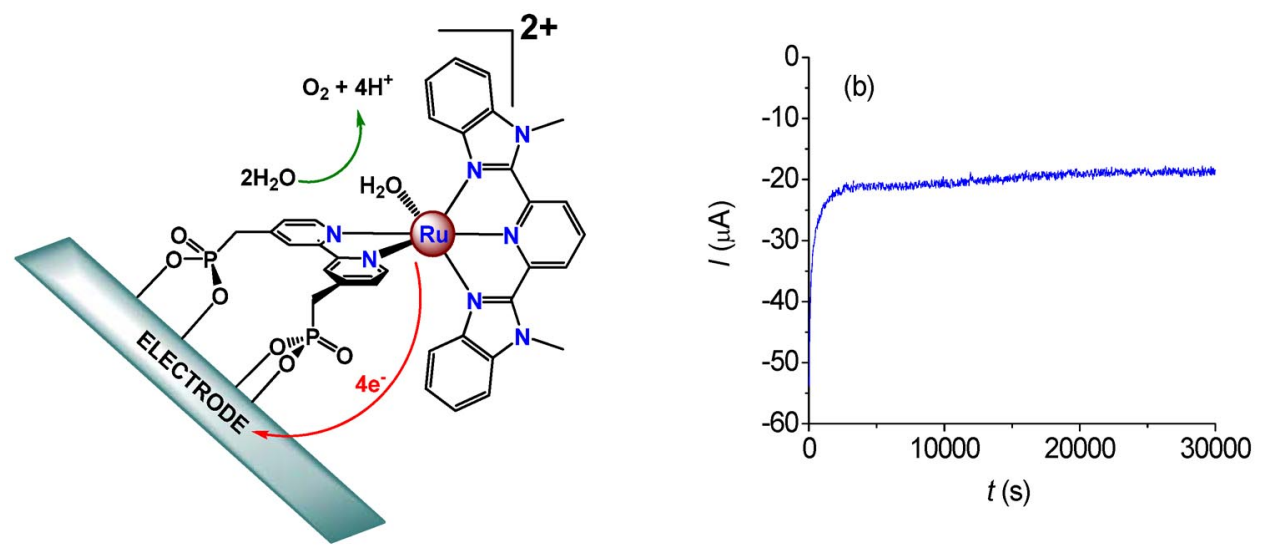

Fig. 12 Electrocatalytic water oxidation by surface bound $\mathrm{Ru}($ Mebimpy $)\left(4,4^{\prime}-\left(\mathrm{H}_{2} \mathrm{O}_{3} \mathrm{PCH}_{2}\right){ }_{2}\right.$ bpy $)\left(\mathrm{H}_{2} \mathrm{O}\right)^{2+}$. On FTO at $1.85 \mathrm{~V}, \mathrm{pH}=5, \Gamma=1.2 \times 10^{-10} \mathrm{~mol} / \mathrm{cm}^{2}$, area $=1.25 \mathrm{~cm}^{2}$ : Turnovers $\sim 11000$, rate $=0.36 \mathrm{~s}^{-1}$, current density $=$ $15 \mu \mathrm{A} / \mathrm{cm}^{2}$. 


\section{CHROMOPHORE CATALYST ASSEMBLIES ON OXIDE SURFACES}

As shown in Fig. 13, water oxidation electrocatalysis has also been extended to a chromophore-catalyst assembly. The example shown is also impressive as a catalyst both in terms of rate and stability with no sign of deterioration after 28000 turnovers. An electrochemical study of the surface-bound catalyst reveals a mechanism analogous to the single-site mechanism in Scheme 6 with the surface RuIII/II couple appearing at $1.33 \mathrm{~V}$ in $0.1 \mathrm{M} \mathrm{HNO}_{3}$ [63].
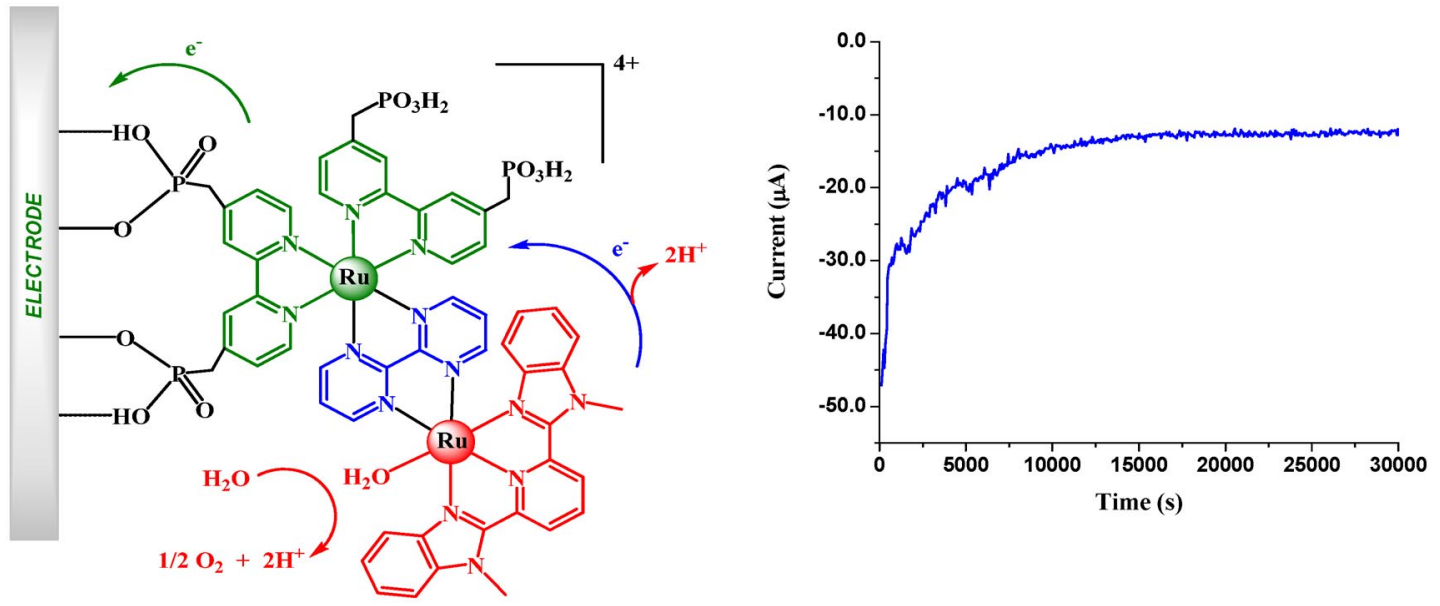

Fig. 13 Electrocatalytic water oxidation by the chromophore-catalyst assembly $\left[\left(4,4^{\prime}-\right.\right.$ $\left.(\mathrm{HO})_{2} \mathrm{OPCH}_{2}\right)_{2}$ bpy $)_{2} \mathrm{Ru}^{\mathrm{II}}(\mathrm{bpm}) \mathrm{Ru}{ }^{\mathrm{II}}($ Mebimpy $\left.)\left(\mathrm{OH}_{2}\right)\right]^{4+}$ on ITO: $\Gamma \sim 7 \times 10^{-11} \mathrm{~mol} / \mathrm{cm}^{2}, \mathrm{~A}=1.95 \mathrm{~cm}^{2}$, turnovers $=28000$, rate $=0.6 \mathrm{~s}^{-1}$ (current density $=13 \mathrm{~mA} / \mathrm{cm}^{2}$ ).

The chromophore-catalyst assembly in Fig. 13 is one of a series currently under investigation for application as photoanodes in water splitting or organic oxidations, note Fig. 7. Initial transient laser and photocurrent measurements on the nanosecond time scale reveal that excitation of the chromophore leads to rapid injection followed by $<$ ns intramolecular electron transfer, eq. 8 . There is also evidence for "remote injection" following excitation of the remote $\mathrm{Ru}^{\mathrm{II}}-\mathrm{OH}_{2}$ side but with low efficiency.

$$
\begin{aligned}
& \mathrm{TiO}_{2}-\mathrm{Ru}^{\mathrm{II}}(\mathrm{bpm}) \mathrm{Ru}^{\mathrm{II}}-\mathrm{OH}_{2}{ }^{4} \stackrel{+h v}{\longrightarrow} \mathrm{TiO}_{2}\left(e^{-}\right)-\mathrm{Ru}^{\mathrm{II}}(\mathrm{bpm}) \mathrm{Ru}^{\mathrm{III}}-\mathrm{OH}_{2}\left(e^{-}\right)-\mathrm{Ru}^{4+}+\mathrm{H}^{+} \\
& \stackrel{\mathrm{III}}{(\mathrm{bpm}) \mathrm{Ru}^{\mathrm{II}}-\mathrm{OH}_{2}}{ }^{5+}
\end{aligned}
$$

Even injection from the chromophore attached to $\mathrm{TiO}_{2}$ is highly inefficient, $<10 \%$. This assembly is inappropriate as the key element for a photoanode, but it has revealed important insights for future design that are being incorporated into third- and fourth-generation assemblies. Key functional elements for success are illustrated in Fig. 14. From the figure: (i) $E^{\circ \prime}$ for the chromophore following injection must be sufficiently positive to drive the highest potential step in the water oxidation cycle. (ii) Light absorption needs to be extended into the low-energy visible-near IR to maximize solar efficiency. (iii) The lowest MLCT excited state should be directed toward the semiconductor surface to maximize injection. (iv) The rate of water oxidation must exceed $1 \mathrm{~s}^{-1}$, the approximate rate of excitation of individual chromophores in the $\mathrm{TiO}_{2}$ film.

With the evolving rules for successful chromophore-catalyst assemblies in mind, we continue to develop the underlying synthetic chemistry of chromophore-catalyst assemblies. Examples of current targets are illustrated in Fig. 15. It seems clear that success in this area will involve an iterative process of design, evaluation, and redesign. Information gathered separately on light absorption, water oxidation catalysis, surface binding, structure, and dynamics with the modular approach will all be incorpo- 


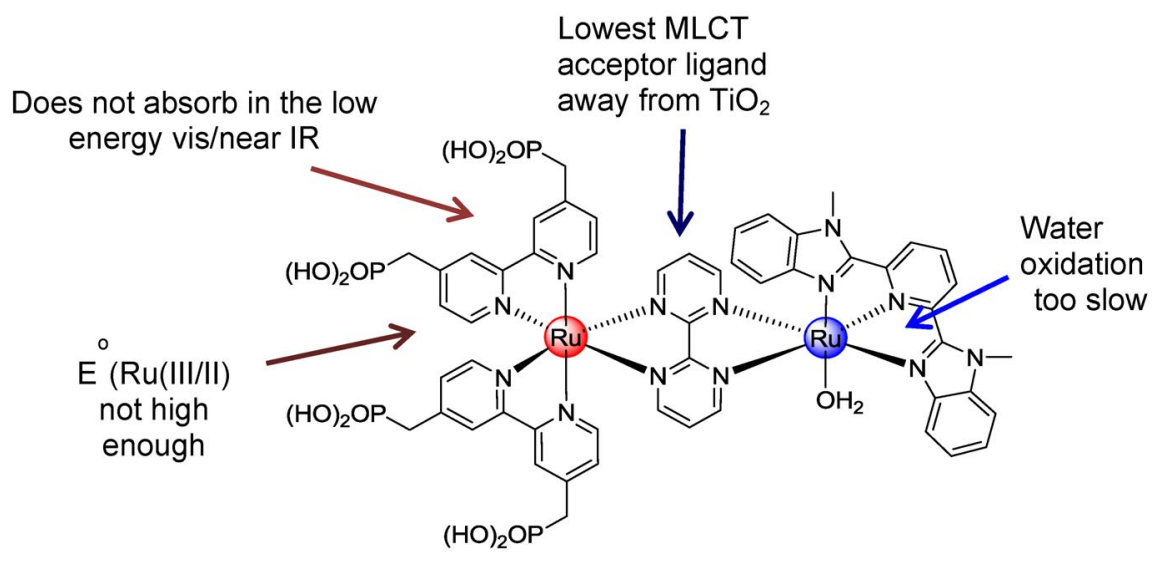

Fig. 14 Important design features and limitations revealed by analysis of $\left\{\left[(\mathrm{HO})_{2} \mathrm{P}(\mathrm{O}) \mathrm{CH}_{2}\right]_{2}\right.$ (bpy) ${ }_{2} \mathrm{Ru}^{\mathrm{II}}(\mathrm{bpm}) \mathrm{Ru}^{\mathrm{II}}\left(\text { tpy') }\left(\mathrm{OH}_{2}\right)\right\}^{4+}$ on $\mathrm{TiO}_{2}$.

rated into successively more efficient designs to the limit that the chemistry can take us. The ultimate goal is a working solar fuels device.

Parallel studies are being pursued. They include $\mathrm{CO}_{2}$ reduction catalysis for the cathode, first-row transition-metal catalysts for water oxidation, semiconductors with more appropriate conduction and valence band energies such as $\mathrm{Nb}_{2} \mathrm{O}_{5}$ and $\mathrm{SrTiO}_{3}$, and tandem cell approaches which utilize photodriven hole injection at $\mathrm{NiO}$.
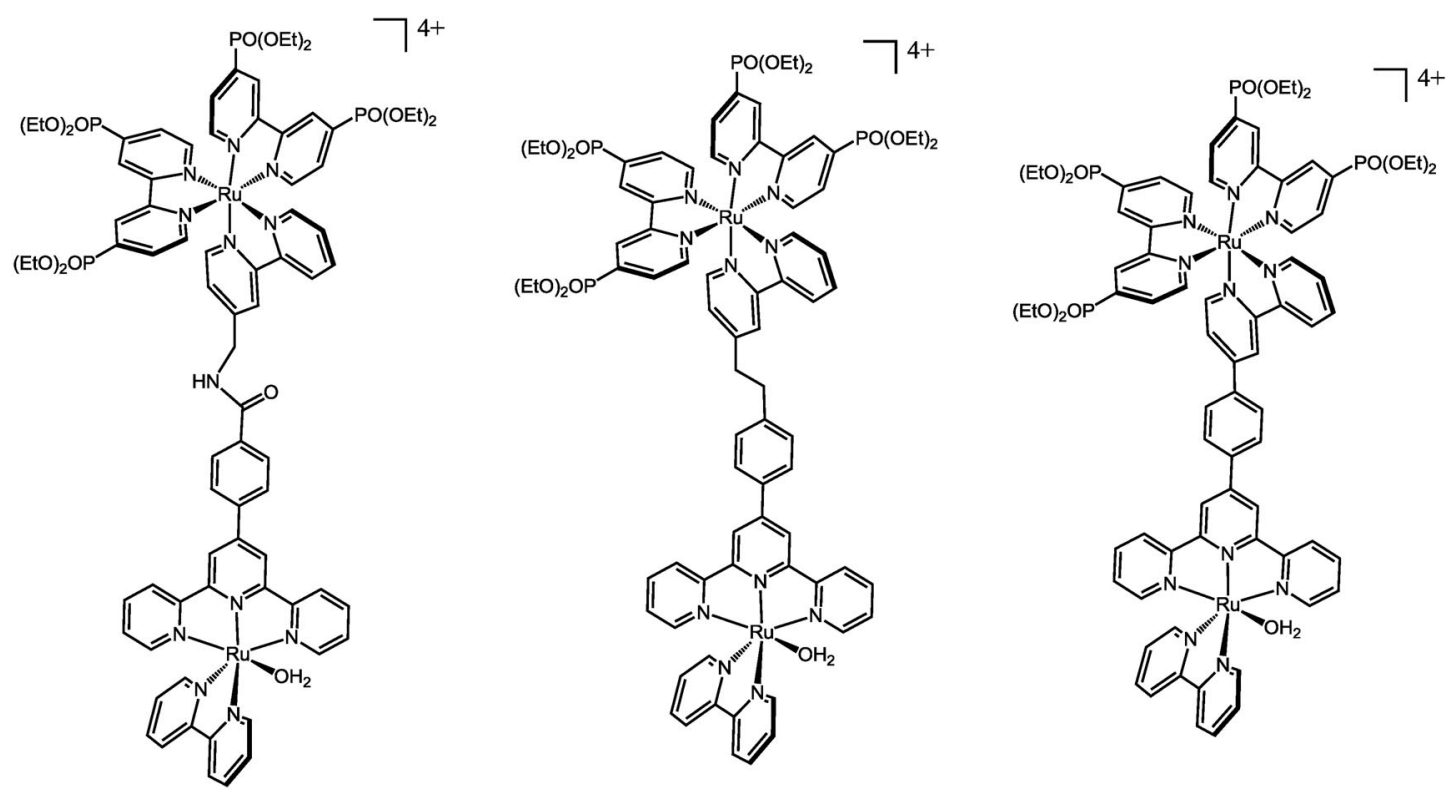

Fig. 15 Examples of target assemblies. 


\section{POSTSCRIPT: THE ROLE OF BASIC RESEARCH}

In closing this account, it is of value to summarize key research findings at the University of North Carolina that led to our current level of understanding and prospects for the future. A summary of "research advances" is listed in Table 1. It begins with the observation of electron-transfer quenching of $\mathrm{Ru}(\mathrm{bpy})_{3}{ }^{2+*}$ and recognition of a new approach to artificial photosynthesis. Research advances and the years in which they first appeared in publications are listed in the Table. It is an impressive list of basic research findings driven by the need to invent something in new order to move the research agenda forward. Much remains to be done.

Table 1 Artificial photosynthesis and solar fuels. Research advances.

\begin{tabular}{|c|c|c|}
\hline Year & Research & Ref. \\
\hline 1974 & $\begin{array}{l}\text { First experimental demonstration of excited-state } \\
\text { electron transfer for } \mathrm{Ru}\left(\text { bpy) }{ }_{3}^{2+*}\right. \\
\text { (with D. G. Whitten) }\end{array}$ & [18-21] \\
\hline 1978 & $\begin{array}{l}\text { First investigation of excited-state electron } \\
\text { transfer in a chromophore-quencher complex }\end{array}$ & {$[64]$} \\
\hline 1981 & Discovery of proton-coupled electron transfer & {$[65]$} \\
\hline 1982 & First molecular catalyst for water oxidation & {$[53,54]$} \\
\hline 1982 & Energy gap law applied to MLCT excited states & [66] \\
\hline 1989 & Chemical approaches to artificial photosynthesis & {$[22]$} \\
\hline 1989 & First interfacial catalysts for $\mathrm{CO}_{2}$ reduction & {$[67]$} \\
\hline 1999 & First dye-sensitized photoelectrosynthesis cell & [39] \\
\hline 2008 & $\begin{array}{l}\text { First solution and surface-bound single-site water } \\
\text { oxidation catalysts }\end{array}$ & {$[55,56]$} \\
\hline
\end{tabular}

\section{ACKNOWLEDGMENTS}

This work is supported by the UNC EFRC: Solar Fuels and Next Generation Photovoltaics, an Energy Frontier Research Center funded by the U.S. Department of Energy, Office of Science, Office of Basic Energy Sciences under Award Number DE-SC0001011 (supporting MKB, JJC and TJM). NYMI and AOTP were supported by the Fundação de Amparo à Pesquisa do Estado de São Paulo (FAPESP) and the Conselho Nacional de Desenvolvimento Científico e Tecnológico (CNPq) and support for WS was provided by the UVA EFRC: Center for Catalytic Hydrocarbon Functionalization, an Energy Frontier Research Center funded by the U.S. Department of Energy, Office of Science, Office of Basic Energy Sciences under Award Number DE-SC0001298. Funding by the Army Research Office through Grant W911NF-09-1-0426 supported ZC.

\section{REFERENCES}

1. R. L. Hirsch, R. Bezdek, R. Wendling. A report sponsored by the National Energy Technology Laboratory of the U.S. Department of Energy (2005).

2. National Research Council of the National Academies. America's Climate Choices: Informing an Effective Response to Climate Change (2010).

3. National Research Council of the National Academies. Hidden Costs of Energy: Unpriced Consequences of Energy Production and Use (2010).

4. United Nations Intergovernmental Panel on Climate Change. Fourth Assessment Report: Climate Change (2007).

5. V. K. Yachandra, K. Sauer, M. P. Klein. Chem. Rev. 96, 2927 (1996).

6. G. Renger, T. Renger. Photosynth. Res. 98, 53 (2008). 
7. T. J. Meyer, M. H. V. Huynh, H. H. Thorp. Angew. Chem., Int. Ed. 46, 5284 (2007).

8. J. P. McEvoy, G. W. Brudvig. Chem. Rev. 106, 4455 (2006).

9. J. Kern, G. Renger. Photosynth. Res. 94, 183 (2007).

10. H. Dau, I. Zaharieva. Acc. Chem. Res. 42, 1861 (2009).

11. G. W. Brudvig. Philos. Trans. R. Soc. B: Bio. Sci. 363, 1211 (2008).

12. J. Barber, B. Andersson. Nature 370, 31 (1994).

13. J. Barber. Biochem. Soc. Trans. 34, 619 (2006).

14. J. Yano, J. Kern, K. Sauer, M. J. Latimer, Y. Pushkar, J. Biesiadka, B. Loll, W. Saenger, J. Messinger, A. Zouni, V. K. Yachandra. Science 314, 821 (2006).

15. B. Loll, J. Kern, W. Saenger, A. Zouni, J. Biesiadka. Nature 438, 1040 (2005).

16. K. N. Ferreira, T. M. Iverson, K. Maghlaoui, J. Barber, S. Iwata. Science 303, 1831 (2004).

17. A. Fujishima, K. Honda. Nature 238, 37 (1972).

18. R. C. Young, T. J. Meyer, D. G. Whitten. J. Am. Chem. Soc. 98, 286 (1976).

19. T. J. Meyer. Pure Appl. Chem. 62, 1003 (1990).

20. C. R. Bock, T. J. Meyer, D. G. Whitten. J. Am. Chem. Soc. 96, 4710 (1974).

21. T. J. Meyer. Pure Appl. Chem. 62, 1003 (1990).

22. T. J. Meyer. Acc. Chem. Res. 22, 163 (1989).

23. D. Gust, T. A. Moore, A. L. Moore. Acc. Chem. Res. 34, 40 (2000).

24. D. Gust, T. A. Moore. The Porphyrin Handbook 8, 153 (1999).

25. M. R. Wasielewski. Chem. Rev. 92, 435 (1992).

26. V. Balzani. Pure Appl. Chem. 62, 1099 (1990).

27. J. H. Alstrum-Acevedo, M. K. Brennaman, T. J. Meyer. Inorg. Chem. 44, 6802 (2005).

28. V. Balzani, A. Credi, M. Venturi. ChemSusChem 1, 26 (2008).

29. M. R. Wasielewski. J. Org. Chem. 71, 5051 (2006).

30. R. Lomoth, A. Magnuson, M. Sjödin, P. Huang, S. Styring, L. Hammarström. Photosynth. Res. 87, 25 (2006).

31. S. Fukuzumi. Eur. J. Inorg. Chem. 1351 (2008).

32. H. G. Park, J. K. Holt. Energy Environ. Sci. 3, 1028 (2010).

33. A. J. Bard, M. A. Fox. Acc. Chem. Res. 28, 141 (1995).

34. V. Balzani. Photochem. Photobiol. Sci. 2, 459 (2003).

35. B. C. O'Regan, M. Gratzel. Nature 353, 737 (1991).

36. B. C. O'Regan, J. R. Durrant. Acc. Chem. Res. 42, 1799 (2009).

37. M. Grätzel. Acc. Chem. Res. 42, 1788 (2009).

38. S. Ardo, G. J. Meyer. Chem. Soc. Rev. 38, 115 (2009).

39. J. A. Treadway, J. A. Moss, T. J. Meyer. Inorg. Chem. 38, 4386 (1999).

40. T. J. Meyer, M. H. V. Huynh. Inorg. Chem. 42, 8140 (2003).

41. W. J. Youngblood, S.-H. A. Lee, Y. Kobayashi, E. A. Hernandez-Pagan, P. G. Hoertz, T. A. Moore, A. L. Moore, D. Gust, T. E. Mallouk. J. Am. Chem. Soc. 131, 926 (2009).

42. D. M. Robinson, Y. B. Go, M. Greenblatt, G. C. Dismukes. J. Am. Chem. Soc. 132, 11467 (2010).

43. L. Li, L. Duan, Y. Xu, M. Gorlov, A. Hagfeldt, L. Sun. Chem. Commun. 46, 7307 (2010).

44. R. Brimblecombe, A. Koo, G. C. Dismukes, G. F. Swiegers, L. Spiccia. J. Am. Chem. Soc. 132, 2892 (2010).

45. W. Ruttinger, G. C. Dismukes. Chem. Rev. 97, 1 (1997).

46. B. A. Moyer, T. J. Meyer. J. Am. Chem. Soc. 100, 3601 (1978).

47. R. A. Binstead, M. E. McGuire, A. Dovletoglou, W. K. Seok, L. E. Roecker, T. J. Meyer. J. Am. Chem. Soc. 114, 173 (1992).

48. B. A. Moyer, T. J. Meyer. Inorg. Chem. 20, 436 (1981).

49. M. H. V. Huynh, T. J. Meyer. Chem. Rev. 107, 5004 (2007).

50. F. Liu, J. J. Concepcion, J. W. Jurss, T. Cardolaccia, J. L. Templeton, T. J. Meyer. Inorg. Chem. 47, 1727 (2008). 
51. J. K. Hurst, J. Zhou, Y. Lei. Inorg. Chem. 31, 1010 (1992).

52. J. K. Hurst. Coord. Chem. Rev. 249, 313 (2005).

53. J. A. Gilbert, D. S. Eggleston, W. R. Murphy, D. A. Geselowitz, S. W. Gersten, D. J. Hodgson, T. J. Meyer. J. Am. Chem. Soc. 107, 3855 (1985).

54. S. W. Gersten, G. J. Samuels, T. J. Meyer. J. Am. Chem. Soc. 104, 4029 (1982).

55. J. J. Concepcion, J. W. Jurss, J. L. Templeton, T. J. Meyer. J. Am. Chem. Soc. 130, 16462 (2008).

56. Z. Chen, J. J. Concepcion, J. W. Jurss, T. J. Meyer. J. Am. Chem. Soc. 131, 15580 (2009).

57. Z. Chen, J. J. Concepcion, X. Hu, W. Yang, P. G. Hoertz, T. J. Meyer. Proc. Natl. Acad. Sci. USA 107, 7225 (2010).

58. J. J. Concepcion, M.-K. Tsai, J. T. Muckerman, T. J. Meyer. J. Am. Chem. Soc. 132, 1545 (2010).

59. J. J. Concepcion, J. W. Jurss, M. R. Norris, Z. Chen, J. L. Templeton, T. J. Meyer. Inorg. Chem. 49, 1277 (2010).

60. J. J. Concepcion, J. W. Jurss, M. K. Brennaman, P. G. Hoertz, A. O. T. Patrocinio, N. Y. Murakami Iha, J. L. Templeton, T. J. Meyer. Acc. Chem. Res. 42, 1954 (2009).

61. Z. Chen, J. J. Concepcion, J. F. Hull, P. G. Hoertz, T. J. Meyer. Dalton Trans. 39, 6950 (2010).

62. P. G. Hoertz, Z. Chen, C. A. Kent, T. J. Meyer. Inorg. Chem. 49, 8179 (2010).

63. J. J. Concepcion, J. W. Jurss, P. G. Hoertz, T. J. Meyer. Angew. Chem., Int. Ed. 48, 9473 (2009).

64. B. P. Sullivan, H. Abruna, H. O. Finklea, D. J. Salmon, J. K. Nagle, T. J. Meyer, H. Sprintschnik. Chem. Phys. Lett. 58, 389 (1978).

65. R. A. Binstead, B. A. Moyer, G. J. Samuels, T. J. Meyer. J. Am. Chem. Soc. 103, 2897 (1981).

66. E. M. Kober, J. V. Caspar, R. S. Lumpkin, T. J. Meyer. J. Phys. Chem. 90, 3722 (1986).

67. T. R. O'Toole, B. P. Sullivan, M. R. M. Bruce, L. D. Margerum, R. W. Murray, T. J. Meyer. J. Electroanal. Chem. 259, 217 (1989). 